Article

\title{
Tetra-, Penta- and Hexa-Coordinated Transition Metal Complexes Constructed from Coumarin-Containing $\mathrm{N}_{2} \mathrm{O}_{2}$ Ligand
}

\author{
Lei Gao, Chang Liu, Fei Wang and Wen-Kui Dong * (1) \\ School of Chemical and Biological Engineering, Lanzhou Jiaotong University, Lanzhou 730070, China; \\ GaoLei19910731@163.com (L.G.); liuchang973914143@126.com (C.L.); wangfei3986@163.com (F.W.) \\ * Correspondence: dongwk@126.com; Tel.: +86-93-1493-8703
}

Received: 10 January 2018; Accepted: 30 January 2018; Published: 1 February 2018

\begin{abstract}
Three newly designed complexes, $[\mathrm{Cu}(\mathrm{L})] \cdot \mathrm{CHCl}_{3}(\mathbf{1}),[\mathrm{Co}(\mathrm{L})(\mathrm{MeOH})] \cdot \mathrm{CHCl}_{3}(\mathbf{2})$ and $\left[\{\mathrm{Ni}(\mathrm{L})(\mathrm{MeOH})(\mathrm{PhCOO})\}_{2} \mathrm{Ni}\right](3)$ a coumarin-containing Salamo-type chelating ligand $\left(\mathrm{H}_{2} \mathrm{~L}\right)$ have been synthesized and characterized by elemental analyses, IR and UV-VIS spectra, and X-ray crystallography. Complex 1 includes one $\mathrm{Cu}(\mathrm{II})$ atom, one completely deprotonated (L) ${ }^{2-}$ unit and one crystalling chloroform molecule, the $\mathrm{Cu}(\mathrm{II})$ atom shows a square-planar geometry. Complex 2 includes one $\mathrm{Co}(\mathrm{II})$ atom, one completely deprotonated $(\mathrm{L})^{2-}$ unit, one coordinated methanol molecule and one crystalling chloroform molecule. The $\mathrm{Co}(\mathrm{II})$ atom is a distorted trigonal-bipyramidal geometry. While complex 3 includes three $\mathrm{Ni}$ (II) atoms, two completely deprotonated (L) ${ }^{2-}$ units, two benzoates and two coordinated methanol molecules. The complexes $\mathbf{1}$ and $\mathbf{2}$ are both possess three-dimensional supra-molecular structures by abundant noncovalent interactions. But, complex 3 formed a two-dimensional supra-molecular structure by intra-molecular hydrogen bonds. In addition, the antimicrobial and fluorescence properties of $\mathrm{H}_{2} \mathrm{~L}$ and its complexes $\mathbf{1}, \mathbf{2}$ and $\mathbf{3}$ were also investigated.
\end{abstract}

Keywords: coumarin-containing $\mathrm{N}_{2} \mathrm{O}_{2}$ ligand; complex; synthesis; crystal structure; property

\section{Introduction}

Salen compound is a kind of versatile tetradentate $\mathrm{N}_{2} \mathrm{O}_{2}$ chelating ligand in modern coordination chemistry [1-7], and its metal complexes have been diffusely investigated in biological fields [8-10], ion recognitions [11], luminescent [12-17] and magnetic [18-21] materials, supra-molecular buildings [22-26] and so on. Especially, some substitution of atoms of the ligand with other elements often evidently improves its properties. When an $\mathrm{O}$-alkyl oxime unit substitutes the imine moiety, the larger electronegativity of the $\mathrm{O}$ atoms is predicted to improve significantly the electronic behaviors of Salamo-type compounds, which may give rise to novel structures and better properties of the metal(II) complexes [27-33].

The introduction of different substituted groups into Salamo-type compounds may give rise to novel structures and the uncoordinated crystalling molecule can also affect the spatial structures [34-36]. Although these Salamo-type complexes have been in the process of development, the fluorescence and antimicrobial properties with coumarin-containing transition metal complexes are still unreported. In this study, three newly designed complexes $[\mathrm{Cu}(\mathrm{L})] \cdot \mathrm{CHCl}_{3}(\mathbf{1}),[\mathrm{Co}(\mathrm{L})(\mathrm{MeOH})] \cdot \mathrm{CHCl}_{3}(2)$ and [ $\left.\{\mathrm{NiL}(\mathrm{MeOH})(\mathrm{PhCOO})\}_{2} \mathrm{Ni}\right]$ (3) have been prepared with a coumarin-containing Salamo-type $\mathrm{N}_{2} \mathrm{O}_{2}$ ligand, in particular the research on the Salamo-type complex contained benzoate ligands is reported firstly. 


\section{Experimental}

\subsection{Materials and Methods}

7-Hydroxyl-4-methyl-coumarin (98\%) was obtained from Alfa Aesar (New York, NY, USA). $\mathrm{C}, \mathrm{H}$ and $\mathrm{N}$ analyses were gained by a GmbH VarioEL V3.00 automatic elemental analysis instrument (Elementar, Berlin, Germany). Elemental analyses for metals were obtained using an IRIS ER/S-WP-ICP atomic emission spectrometer (Elementar, Berlin, Germany). Melting points were measured by the use of a microscopic melting point apparatus made by Beijing Taike Instrument Limited Company (Beijing, China) and were uncorrected. IR spectra were recorded on a Vertex70 FT-IR spectrophotometer, with samples prepared as $\mathrm{KBr}\left(400-4000 \mathrm{~cm}^{-1}\right)$ pellets (Bruker AVANCE, Billerica, MA, USA). UV-VIS absorption spectra were measured on a Shimadzu UV-3900 spectrometer (Shimadzu, Tokyo, Japan). Luminescence spectra in solution were recorded on a Hitachi F-7000 spectrometer (Shimadzu, Tokyo, Japan). ${ }^{1} \mathrm{H}-\mathrm{NMR}$ spectra were measured by a German Bruker AVANCE DRX-400 spectrometer (Bruker AVANCE, Billerica, MA, USA). X-ray single-crystal structures were determined by a SuperNova Dual (Cu at zero) and Bruker APEX-II CCD diffractometers (Bruker AVANCE, Billerica, MA, USA), respectively.

\subsection{Synthesis of $\mathrm{H}_{2} \mathrm{~L}$}

Major reaction step, $O, O^{\prime}$-ethane-1,2-diyl-bis-hydroxylamine was prepared following the literature [37-39]. 7-Hydroxy-4-methyl-2-oxo-2H-chromene-8-carbonitrile was synthesized in accordance with the reported procedures [40]. The major reaction steps participated in the preparation of $\mathrm{H}_{2} \mathrm{~L}$ are shown in Scheme 1.

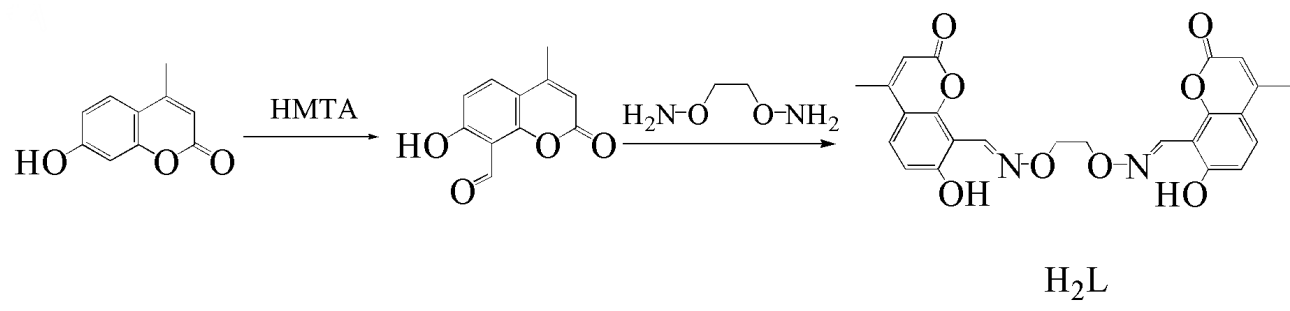

Scheme 1. Synthetic route to $\mathrm{H}_{2} \mathrm{~L}$.

An ethanol solution (15 mL) of 7-Hydroxy-4-methyl-2-oxo-2H-chromene-8-carbonitrile (384.38 $\mathrm{mg}, 1.45 \mathrm{mmol}$ ) was added dropwise to an ethanol solution (15 mL) of $O, O^{\prime}$-ethane-1, 2-diyl-bis-hydroxylamine $(46.00 \mathrm{mg}, 0.5 \mathrm{mmol})$ in ethanol $(15 \mathrm{~mL})$ and the mixture was subjected to heating at $65 \sim 70{ }^{\circ} \mathrm{C}$ for $3 \mathrm{~h}$. After cooling to the room temperature, the resulting white solid was collected. Yield, $186.47 \mathrm{mg}, 0.40 \mathrm{mmol}(80.3 \%)$. Anal. Calcd for $\mathrm{C}_{24} \mathrm{H}_{20} \mathrm{~N}_{2} \mathrm{O}_{8}(\%)$ : C, 62.07; $\mathrm{H}, 4.34 ; \mathrm{N}$, 6.03; Found: $\mathrm{C}, 62.25 ; \mathrm{H}, 4.47 ; \mathrm{N}, 5.89 .{ }^{1} \mathrm{H}-\mathrm{NMR}\left(400 \mathrm{MHz}, \mathrm{CDCl}_{3}\right), \delta 10.72(\mathrm{~s}, 2 \mathrm{H}, \mathrm{OH}), 8.95(\mathrm{~s}, 2 \mathrm{H}$, $\mathrm{CH}=\mathrm{N}), 7.50(\mathrm{~d}, J=8.9 \mathrm{~Hz}, 2 \mathrm{H}, \mathrm{ArH}), 6.93(\mathrm{~d}, J=8.9 \mathrm{~Hz}, 2 \mathrm{H}, \mathrm{ArH}), 6.14(\mathrm{~s}, 2 \mathrm{H}, \mathrm{ArH}), 4.54\left(\mathrm{~s}, 4 \mathrm{H}, \mathrm{CH}_{2}\right)$, $2.40\left(\mathrm{~s}, 6 \mathrm{H}, \mathrm{CH}_{3}\right)$.

\subsection{Synthesis of Complex $\mathbf{1}$}

A chloroform solution $(4 \mathrm{~mL})$ of $\mathrm{H}_{2} \mathrm{~L}(4.64 \mathrm{mg}, 0.01 \mathrm{mmol})$ was added dropwise to a methanol solution $(4 \mathrm{~mL})$ of $\mathrm{Cu}(\mathrm{OAc})_{2} \cdot \mathrm{H}_{2} \mathrm{O}(1.99 \mathrm{mg}, 0.01 \mathrm{mmol})$, the color of the mixed solution changes immediately to dark green. The mixed solution was filtered, and the filtrate was kept undisturbed in the dark to avoid decomposition of the coumarin-containing building blocks. Single-crystals suitable for X-ray crystallography were grown up by partial solvent evaporation after about two weeks, and collected carefully by filtration, washed with n-hexane, and dried at room temperature. Yield, $3.01 \mathrm{mg}, 0.0047 \mathrm{mmol}(46.7 \%)$. Anal. Calc. for $\mathrm{C}_{25} \mathrm{H}_{19} \mathrm{Cl}_{3} \mathrm{CuN}_{2} \mathrm{O}_{8}(\%)$ : C, 46.53; H, 2.97; N, 4.34; $\mathrm{Cu}$, 9.85; Found: C, 46.69; H, 3.02; N, 4.17; Cu, 9.71. 


\subsection{Synthesis of Complex $\mathbf{2}$}

A solution of $\mathrm{H}_{2} \mathrm{~L}$ ( $\left.4.64 \mathrm{mg}, 0.01 \mathrm{mmol}\right)$ in $4 \mathrm{~mL}$ of chloroform was added dropwise to a methanol solution $(6 \mathrm{~mL})$ of $\mathrm{Co}\left(\mathrm{NO}_{3}\right)_{2} \cdot 6 \mathrm{H}_{2} \mathrm{O}(2.91 \mathrm{mg}, 0.01 \mathrm{mmol})$. The color of the mixed solution changes immediately to brown. The mixed solution was filtered, and the filtrate kept undisturbed in the dark to avoid decomposition of the coumarin-containing building blocks. Single-crystals suitable for X-ray crystallography were grown up by partial solvent evaporation after about one week, and collected carefully by filtration, washed with n-hexane, and dried at room temperature. Yield, $3.32 \mathrm{mg}$, 0.0049 mmol (49.3\%). Anal. Calc. for $\mathrm{C}_{26} \mathrm{H}_{23} \mathrm{Cl}_{3} \mathrm{CoN}_{2} \mathrm{O}_{9}(\%)$ : C, 46.42; $\mathrm{H}, 3.45 ; \mathrm{N}, 4.16 ; \mathrm{Co}, 8.76$; Found: C, $46.61 ; \mathrm{H}, 3.57 ; \mathrm{N}, 4.02 ; \mathrm{Co}, 8.61$.

\subsection{Synthesis of Complex 3}

A chloroform solution $(4 \mathrm{~mL})$ of $\mathrm{H}_{2} \mathrm{~L}(4.64 \mathrm{mg}, 0.01 \mathrm{mmol})$ was added dropwise to a methanol solution $(2 \mathrm{~mL})$ of $\mathrm{Ni}\left(\mathrm{NO}_{3}\right)_{2} \cdot 6 \mathrm{H}_{2} \mathrm{O}(2.90 \mathrm{mg}, 0.01 \mathrm{mmol})$. Then, a methanol solution $(5 \mathrm{~mL})$ of sodium benzoic $(1.22 \mathrm{mg}, 0.01 \mathrm{mmol})$ was added, and the mixed sulution was kept stirring for $5 \mathrm{~min}$ at room temperature. The mixed solution was filtered, and the filtrate kept undisturbed in the dark to avoid decomposition of the coumarin-containing building blocks. Single-crystals suitable for X-ray crystallography were grown up by partial solvent evaporation after about three weeks, and collected carefully by filtration, washed with n-hexane, and dried at room temperature. Yield, $2.05 \mathrm{mg}, 0.0015 \mathrm{mmol}(43.7 \%)$. Anal. Calc. for $\mathrm{C}_{64} \mathrm{H}_{54} \mathrm{~N}_{4} \mathrm{Ni}_{3} \mathrm{O}_{22}(\%)$ : C, 54.62; H, 3.87; N, 3.98; Ni, 12.51; Found: $\mathrm{C}, 54.81 ; \mathrm{H}, 3.93 ; \mathrm{N}, 3.83 ; \mathrm{Ni}, 12.33$.

\subsection{X-ray Crystal Structure Determinations for Complexes $\mathbf{1}, \mathbf{2}$ and $\mathbf{3}$}

X-ray single crystal diffraction data of the complexes 1, 2 and $\mathbf{3}$ were recorded using a SuperNova

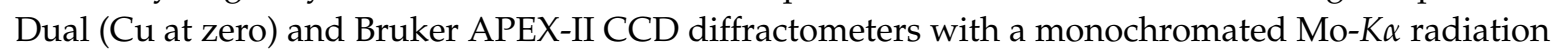
$(\lambda=0.71073 \AA)$ source at 296(2), 173.00(10) and 153(2) K, respectively. The LP corrections were applied to the SAINT program [41] and Semi-empirical correction were applied to the SADABS program [42]. The single crystal structures were solved by the direct methods (SHELXS-2014) [43]. All hydrogen atoms were added theoretically and difference-Fourier map exhibited the positions of the remaining atoms. The $\mathrm{H}$ atoms were included at the calculated positions and constrained to ride on their parent atoms. All non-hydrogen atoms were refined anisotropically by a full-matrix least-squares procedure on $F^{2}$ with SHELXL-2014 [43]. Crystal data and refinement parameters involved the structure determinations are presented in Table 1.

Table 1. Crystal data and refinement parameters for complexes 1, 2 and 3.

\begin{tabular}{cccc}
\hline Complex & $\mathbf{1}$ & $\mathbf{2}$ & $\mathbf{3}$ \\
\hline Formula & $\mathrm{C}_{25} \mathrm{H}_{19} \mathrm{Cl}_{3} \mathrm{CuN}_{2} \mathrm{O}_{8}$ & $\mathrm{C}_{26} \mathrm{H}_{23} \mathrm{Cl}_{3} \mathrm{CoN}_{2} \mathrm{O}_{9}$ & $\mathrm{C}_{64} \mathrm{H}_{54} \mathrm{~N}_{4} \mathrm{Ni}_{3} \mathrm{O}_{22}$ \\
Formula weight & 645.31 & 672.74 & 1407.24 \\
Temperature $(\mathrm{K})$ & $296(2)$ & $173.00(10)$ & $153(2)$ \\
Wavelength $(\AA)$ & 0.71073 & 0.71073 & 0.71073 \\
Crystal system & Monoclinic & Monoclinic & Triclinic \\
Space group & $P{ }_{1} / \mathrm{c}$ & $P{ }_{1} / \mathrm{c}$ & $P-1$ \\
Unit cell dimensions & & & \\
$a(\AA)$ & $13.5401(9)$ & $12.1129(5)$ & $12.6250(18)$ \\
$b(\AA)$ & $6.8318(5)$ & $13.5779(3)$ & $12.6344(17)$ \\
$c(\AA)$ & $27.1822(16)$ & $16.7455(6)$ & $14.7046(18)$ \\
$\alpha\left({ }^{\circ}\right)$ & 90 & 90 & $113.420(4)$ \\
$\beta\left(^{\circ}\right)$ & $94.8504(19)$ & $100.038(3)$ & $95.978(5)$ \\
$\gamma\left({ }^{\circ}\right)$ & 90 & 90 & $107.557(2)$ \\
$V\left(\AA^{3}\right)$ & $2505.4(3)$ & $2711.93(15)$ & $1983.6(5)$ \\
$Z$ & 4 & 4 & 1 \\
$D_{c}\left(\mathrm{~g} \mathrm{~cm}^{-3}\right)$ & 1.711 & 1.648 & 1.178 \\
$\mu\left(\mathrm{mm}^{-1}\right)$ & 1.247 & 0.987 & 0.770 \\
\hline
\end{tabular}


Table 1. Cont

\begin{tabular}{cccc}
\hline Complex & $\mathbf{1}$ & $\mathbf{2}$ & $\mathbf{3}$ \\
\hline$F(000)$ & 1308 & 1372 & 726 \\
Crystal size $(\mathrm{mm})$ & $0.26 \times 0.22 \times 0.19$ & $0.16 \times 0.07 \times 0.04$ & $0.22 \times 0.19 \times 0.18$ \\
$\theta$ Range $\left(^{\circ}\right)$ & $2.219-25.005$ & $3.416-26.020$ & $1.750-25.010$ \\
& $-16 \leq \mathrm{h} \leq 16$, & $-9 \leq \mathrm{h} \leq 14$, & $-13 \leq \mathrm{h} \leq 15$ \\
Index ranges & $-8 \leq \mathrm{k} \leq 6$ & $-16 \leq \mathrm{k} \leq 15$ & $-15 \leq \mathrm{k} \leq 15$ \\
& $-32 \leq 1 \leq 31$ & $-20 \leq 1 \leq 20$ & $-17 \leq 1 \leq 16$ \\
Reflections collected & 16385 & 10655 & 14781 \\
Independent reflections & 4402 & 5343 & 6919 \\
$R_{\text {int }}$ & 0.0746 & 0.0410 & 0.0661 \\
Completeness & $99.9 \%$ & $99.7 \%$ & $99.0 \%$ \\
Data/restraints/parameters & $4402 / 0 / 354$ & $5343 / 4 / 376$ & $6919 / 69 / 319$ \\
GOF & 1.097 & 1.053 & 1.050 \\
Final $R_{1}, w R_{2}$ indices & $0.0659,0.1066$ & $0.0585,0.1315$ & $0.0579,0.1580$ \\
$R_{1}, w R_{2}$ indices (all data) & $0.1058,0.1207$ & $0.0861,0.1530$ & $0.0890,0.1779$ \\
Largest differences & $0.364 /-0.439$ & $1.211 /-0.653$ & $0.935 /-0.828$ \\
& peak and hole $\left(\mathrm{e} \AA^{-3}\right)$ &
\end{tabular}

Crystallographic data have been deposited with the Cambridge Crystallographic Data Centre as supplementary publication, No. CCDC 1,816,001, 1,816,000 and 1,816,002 for complexes 1, 2 and 3, respectively. Copies of the data can be gained free of charge on application to CCDC, 12 Union Road, Cambridge CB21EZ, UK (Telephone: (44) 01223 762910; Fax: +44-1223-336033; E-mail: deposit@ccdc.cam.ac.uk). These data can be also obtained free of charge at www.ccdc.cam.Ac.uk/ conts/retrieving.html.

\section{Results and Discussion}

Complexes 1, 2 and 3 a coumarin-containing Salamo-type ligand have been prepared, and characterized by IR, UV-VIS and X-ray crystallography methods. In addition, the fluorescence properties of complexes 1, 2 and 3 and antimicrobial activities of $\mathrm{H}_{2} \mathrm{~L}$ and its complexes 1, 2 and 3 were also investigated.

\subsection{IR Spectra}

The FT-IR spectra of $\mathrm{H}_{2} \mathrm{~L}$ with its corresponding complexes $\mathbf{1}, 2$ and $\mathbf{3}$ possess different bands in the $4000-400 \mathrm{~cm}^{-1}$ region (Figure 1 and Table 2).

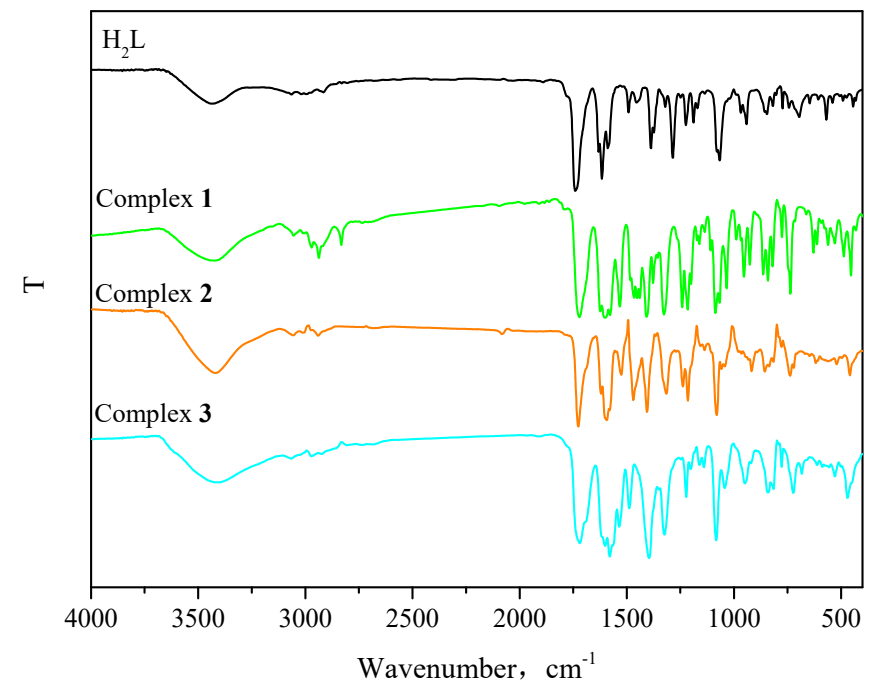

Figure 1. The FT-IR spectra of $\mathrm{H}_{2} \mathrm{~L}$ and its complexes 1,2 and $3\left(\mathrm{~cm}^{-1}\right)$. 
Table 2. The major FT-IR spectra of $\mathrm{H}_{2} \mathrm{~L}$ and its complexes 1, 2 and $3\left(\mathrm{~cm}^{-1}\right)$.

\begin{tabular}{ccccc}
\hline Compound & $v_{(\mathrm{C}=\mathrm{N})}$ & $\boldsymbol{v}_{(\mathrm{Ar}-\mathrm{O})}$ & $\boldsymbol{v}_{(\mathrm{C}=\mathrm{O})}$ & $\boldsymbol{v}_{(\mathrm{C}=\mathrm{C})}$ \\
\hline $\mathrm{H}_{2} \mathrm{~L}$ & 1616 & 1282 & 1734 & 1386 \\
Complex 1 & 1601 & 1242 & 1722 & 1320 \\
Complex 2 & 1597 & 1238 & 1726 & 1312 \\
Complex 3 & 1605 & 1222 & 1719 & 1325 \\
\hline
\end{tabular}

The characteristic $\mathrm{C}=\mathrm{O}$ stretching band at $1734 \mathrm{~cm}^{-1}$ of the ligand $\mathrm{H}_{2} \mathrm{~L}$, and those of the complexes 1, 2 and 3 emerge at 1722, 1726 and $1719 \mathrm{~cm}^{-1}$, respectively [44]. Meanwhile, a characteristic $\mathrm{C}=\mathrm{N}$ stretching band of $\mathrm{H}_{2} \mathrm{~L}$ emerges at $1616 \mathrm{~cm}^{-1}$, and those of complexes $\mathbf{1}, \mathbf{2}$ and 3 show at 1601 , 1597 and $1605 \mathrm{~cm}^{-1}$, respectively [45]. The characteristic $\mathrm{C}=\mathrm{N}$ stretching frequencies are moved to low frequencies, which indicates that the metal(II) atoms are bonded by azomethine $\mathrm{N}$ atoms of the ligand $(\mathrm{L})^{2-}$ moieties [46]. $\mathrm{H}_{2} \mathrm{~L}$ presents a characteristic Ar-O stretching frequency at $1282 \mathrm{~cm}^{-1}$, while those of complexes 1, 2 and 3 emerge at 1242, 1238 and $1222 \mathrm{~cm}^{-1}$, respectively. The characteristic Ar-O stretching frequencies are moved to low frequencies, which can be evidence for formation of $\mathrm{Cu}-\mathrm{O}$, $\mathrm{Co}-\mathrm{O}$ and $\mathrm{Ni}-\mathrm{O}$ bonds between $\mathrm{Cu}(\mathrm{II}), \mathrm{Co}(\mathrm{II})$ and $\mathrm{Ni}(\mathrm{II})$ atoms with $\mathrm{O}$ atoms of phenolic groups [47].

\subsection{UV-VIS Spectra}

The UV-VIS absorption spectra of $\mathrm{H}_{2} \mathrm{~L}$ with its complexes 1, 2 and $\mathbf{3}$ in the dichloromethane solutions $\left(2.0 \times 10^{-5} \mathrm{M}\right)$ at $298 \mathrm{~K}$ are shown in Figure 2 and Table 3. The absorption peaks of $\mathrm{H}_{2} \mathrm{~L}$ are different from its complexes 1, 2 and 3 . The absorption spectrum of $\mathrm{H}_{2} \mathrm{~L}$ comprises three relatively intense absorption peaks centered at 291, 330 and $345 \mathrm{~nm}$, the first peak at $291 \mathrm{~nm}$ can be assigned to the $\pi-\pi^{*}$ transitions of the phenyl rings [48], the second peak at $330 \mathrm{~nm}$ can be assigned to the $\pi-\pi^{*}$ transitions of the oxime group [49], and the third peak at $345 \mathrm{~nm}$ can be assigned to the $\mathrm{n}-\pi^{*}$ transitions of lactone carbonyl group [50]. Upon coordination of $\mathrm{H}_{2} \mathrm{~L}$, the $\pi-\pi^{*}$ transitions of the phenyl rings in complexes 1 and 2 are bathochromically shifted to 299 and $297 \mathrm{~nm}$, respectively, and the absorption peak at $291 \mathrm{~nm}$ vanishes from the UV-VIS spectrum of complex 3, indicating the coordination of $\mathrm{Co}(\mathrm{II}), \mathrm{Cu}(\mathrm{II})$ and $\mathrm{Ni}(\mathrm{II})$ atoms with the $(\mathrm{L})^{2-}$ units [48]. Compared with $\mathrm{H}_{2} \mathrm{~L}$, the absorption peak at $330 \mathrm{~nm}$ vanishes from the UV-VIS spectra of complexes 1, 2 and 3, indicating that the oxime $\mathrm{N}$ atoms are participated in coordination to the $\mathrm{Cu}(\mathrm{II}), \mathrm{Co}(\mathrm{II})$ and $\mathrm{Ni}(\mathrm{II})$ atoms [49]. Meanwhile, the $n-\pi^{*}$ transitions of the lactone carbonyl group in complexes $\mathbf{1}, \mathbf{2}$ and $\mathbf{3}$ assumes a hypsochromic shift to 343,347 and $338 \mathrm{~nm}$ exhibiting that the coordination of the (L) ${ }^{2-}$ units with $\mathrm{Cu}(\mathrm{II}), \mathrm{Co}(\mathrm{II})$ and $\mathrm{Ni}(\mathrm{II})$ atoms, respectively. Meanwhile, three weak broad absorption peaks are gained at 396, 399 and $391 \mathrm{~nm}$ for complexes 1, 2 and 3, respectively, these new absorption peaks can be attributed to $\mathrm{L} \rightarrow \mathrm{M}$ charge-transfer transitions (LMCT). This is characteristic of $\mathrm{N}_{2} \mathrm{O}_{2}$-donors sphere with the transition metal complexes [49].

\subsection{Fluorescence Properties}

The fluorescent properties of $\mathrm{H}_{2} \mathrm{~L}$ and its complexes $\mathbf{1}, \mathbf{2}$ and $\mathbf{3}$ were measured at room temperature (Figure 3). The ligand $\mathrm{H}_{2} \mathrm{~L}$ exhibits a strong and broad emission at $432 \mathrm{~nm}$ upon excitation at $351 \mathrm{~nm}$, which should be assigned to intraligand $\pi-\pi^{*}$ transition [12]. The complexes $\mathbf{1}, \mathbf{2}$ and 3 display weakened photoluminescence with maximum emission peaks at ca. 417, 462 and $469 \mathrm{~nm}$ upon excitation at $351 \mathrm{~nm}$, respectively. The absorption peaks are bathochromically-shifted of complexes 1 and 2, and hypsochromically-shifted of complex 3, which could be attributed to LMCT [12]. 


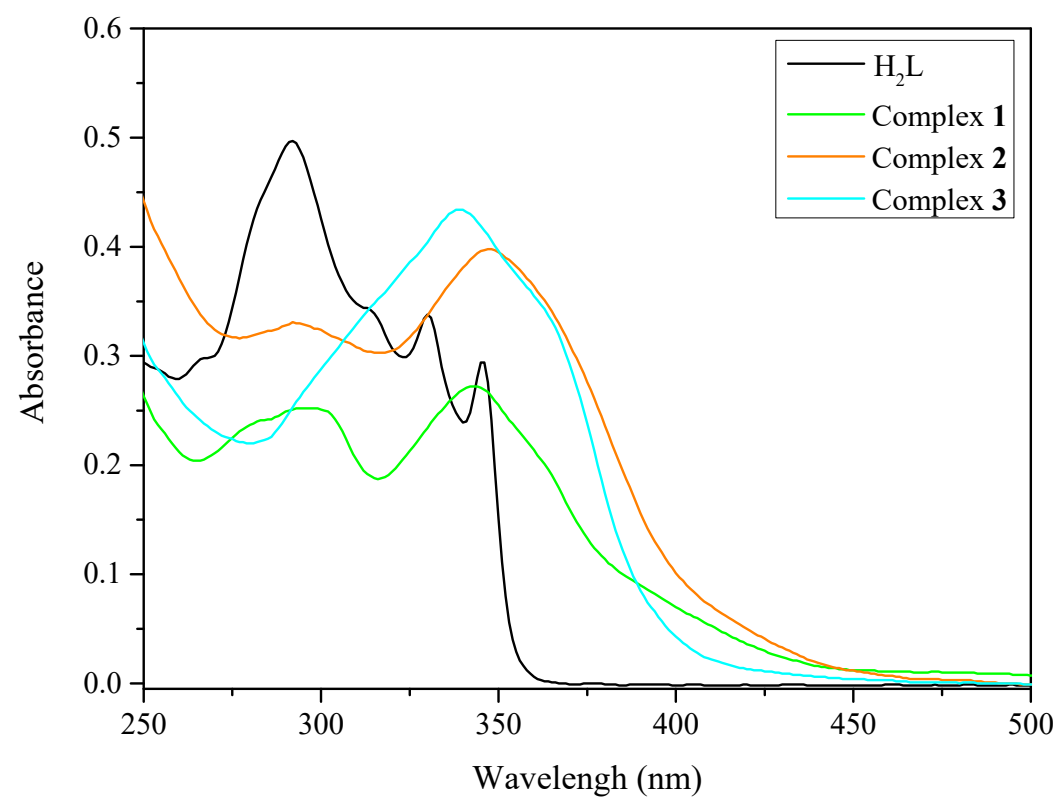

Figure 2. The UV-VIS spectra of $\mathrm{H}_{2} \mathrm{~L}$ and its complexes 1,2 and $3\left(\mathrm{~cm}^{-1}\right)$.

Table 3. Absorption maxima and molar extinction coefficients for $\mathrm{H}_{2} \mathrm{~L}$ and its complexes 1, 2 and 3.

\begin{tabular}{|c|c|c|c|c|c|c|}
\hline Compound & $\lambda \max 1, \mathrm{~nm}$ & $\varepsilon \max 1, \mathrm{M}^{-1} \cdot \mathrm{cm}^{-1}$ & $\lambda \max 2, \mathrm{~nm}$ & $\varepsilon \max 2, \mathrm{M}^{-1} \cdot \mathrm{cm}^{-1}$ & $\lambda \max 3, \mathrm{~nm}$ & $\varepsilon \max 3, \mathrm{M}^{-1} \cdot \mathrm{cm}^{-1}$ \\
\hline $\mathrm{H}_{2} \mathrm{~L}$ & 291 & $4.9 \times 10^{-4}$ & 330 & $3.3 \times 10^{-4}$ & 345 & $2.9 \times 10^{-4}$ \\
\hline Complex 1 & 299 & $2.5 \times 10^{-4}$ & 343 & $2.7 \times 10^{-4}$ & 396 & $0.7 \times 10^{-4}$ \\
\hline Complex 2 & 297 & $3.2 \times 10^{-4}$ & 347 & $3.9 \times 10^{-4}$ & 399 & $0.9 \times 10^{-4}$ \\
\hline Complex 3 & 338 & $4.3 \times 10^{-4}$ & 391 & $0.7 \times 10^{-4}$ & & \\
\hline
\end{tabular}

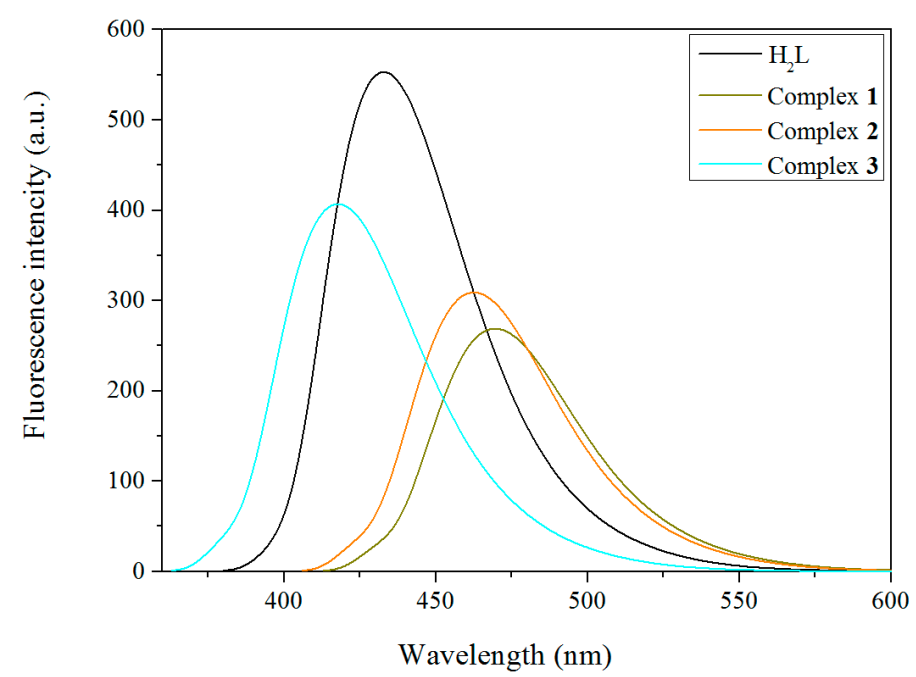

Figure 3. Emission spectra of $\mathrm{H}_{2} \mathrm{~L}$ and its complexes 1, 2 and 3 in dichloromethane $\left(2.5 \times 10^{-5} \mathrm{M}\right)$ upon excitation at $351 \mathrm{~nm}$.

\subsection{Crystal Structure Description of Complex 1}

As presented in Figure 4 and Table 4, complex 1 crystallizes in the monoclinic system, space group $P 2_{1} / c$, which comprises one $\mathrm{Cu}(\mathrm{II})$ atom, one deprotonated $(\mathrm{L})^{2-}$ unit and one crystalling chloroform molecule. 
(a)

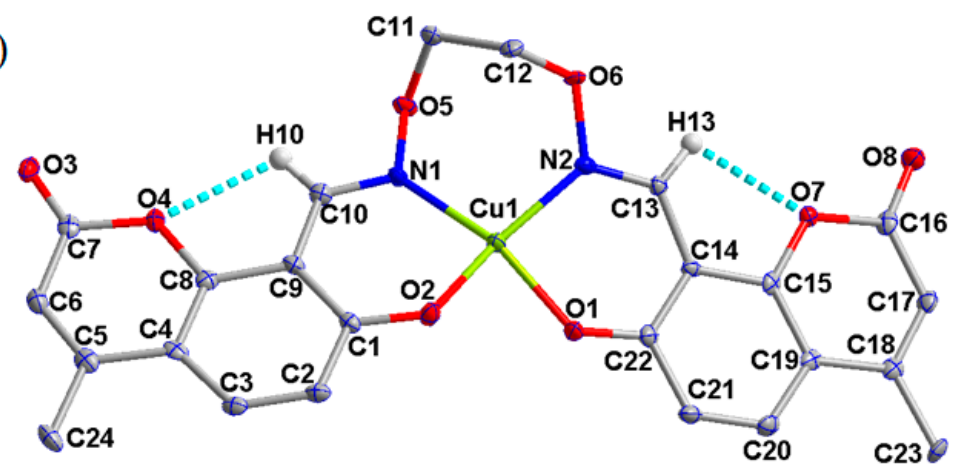

(b)

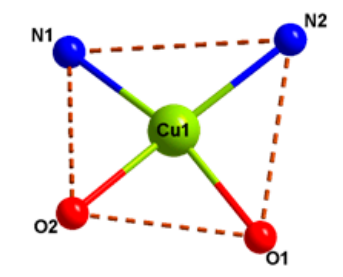

Figure 4. (a) X-ray crystal structure and atom numbering of complex 1 with $30 \%$ probability displacement ellipsoids; (b) Coordination polyhedron of $\mathrm{Cu}(\mathrm{II})$ atom of complex $\mathbf{1}$.

Table 4. Selected bond lengths $(\AA)$ and angles $\left(^{\circ}\right)$ for complex 1.

\begin{tabular}{cclc}
\hline Bond & & & \\
\hline Cu1-O1 & $1.891(3)$ & Cu1-N1 & $1.950(4)$ \\
Cu1-O2 & $1.909(3)$ & Cu1-N2 & $1.976(4)$ \\
\hline Angles & & & \\
\hline O1-Cu1-O2 & $83.86(14)$ & O1-Cu1-N2 & $90.30(15)$ \\
O1-Cu1-N1 & $162.19(18)$ & O2-Cu1-N2 & $161.44(17)$ \\
O2-Cu1-N1 & $89.28(15)$ & N1-Cu1-N2 & $100.99(16)$ \\
\hline
\end{tabular}

The $\mathrm{Cu}(\mathrm{II})$ atom is tetra-coordinated by two oxime $\mathrm{N}$ ( $\mathrm{N} 1$ and $\mathrm{N} 2$ ) atoms and two deprotonated phenoxo $\mathrm{O}(\mathrm{O} 1$ and $\mathrm{O} 2)$ atoms, the four atoms are all from one deprotonated (L) ${ }^{2-}$ unit (Figure $\left.4 \mathrm{a}\right)$. Geometry of $\mathrm{Cu}(\mathrm{II})$ atom can be best described as a slightly distorted square-planar with $\mathrm{CuN}_{2} \mathrm{O}_{2}$ coordination and deduced by using $\tau_{4}$ index, $\tau_{4}=0.258$ (Figure $4 \mathrm{~b}$ ) [51]. The two phenolic $\mathrm{O}(\mathrm{O} 1$ and $\mathrm{O} 2$ ) atoms and the two oxime $\mathrm{N}\left(\mathrm{N} 1\right.$ and N2) atoms of the $(\mathrm{L})^{2-}$ unit compose together the basal (Cu1-O1, 1.891(3); Cu1-O2, 1.909(3); Cu1-N1, 1.950(4) and Cu1-N2, 1.976(4) A) with N2 and O2 above average by $0.239(2)$ and $0.292(2) \AA$, and N1 and O1 below average by $0.241(2)$ and $0.289(2) \AA$, respectively. Additionally, dihedral angles between the basal planes $\left(\mathrm{N}_{2} \mathrm{O}_{2}\right.$ plane $)$ and the benzene rings are $13.17(2)^{\circ}$ and $14.74(2)^{\circ}$, respectively, which defined as shown in Figure 5a. Dihedral angle of planes N1-Cu1-N2 and O1-Cu1-O2 is 22.37(2) (Figure 5b) [52].

\section{(a)}

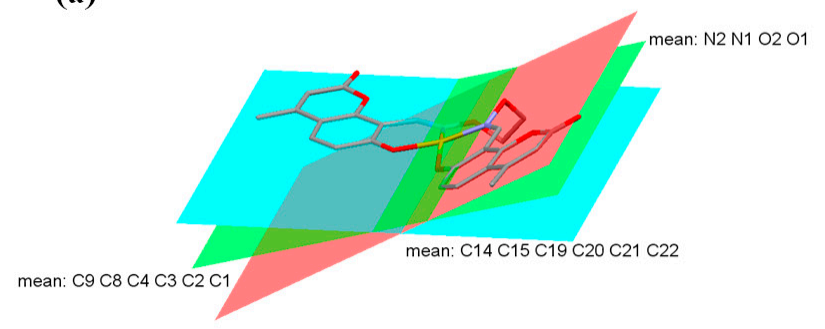

(b)

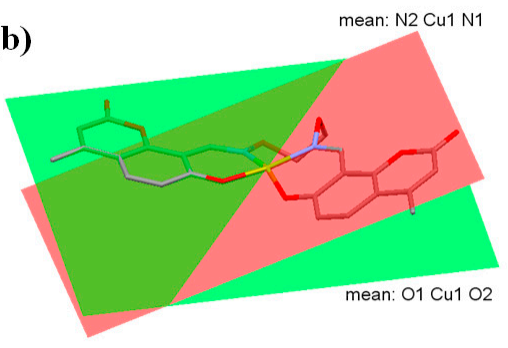

Figure 5. (a) View of the dihedral angles between the benzene rings and the $\mathrm{N}_{2} \mathrm{O}_{2}$ basal plane of complex 1; (b) View of the dihedral angles between planes $\mathrm{CuN}_{2}$ and $\mathrm{CuO}_{2}$ of complex 1 .

As illustrated in Figure 6 and Table 5, complex 1 molecules form an infinite three-dimensional supra-molecular structure by inter-molecular hydrogen bonds, four pairs of inter-molecular hydrogen bonds C12-H12B $\cdots \mathrm{O} 1, \mathrm{C} 20-\mathrm{H} 20 \cdots \mathrm{O} 3, \mathrm{C} 25-\mathrm{H} 25 \cdots \mathrm{O} 8$ and C12-H12A $\cdots \mathrm{Cl} 1$ are formed [53]. 


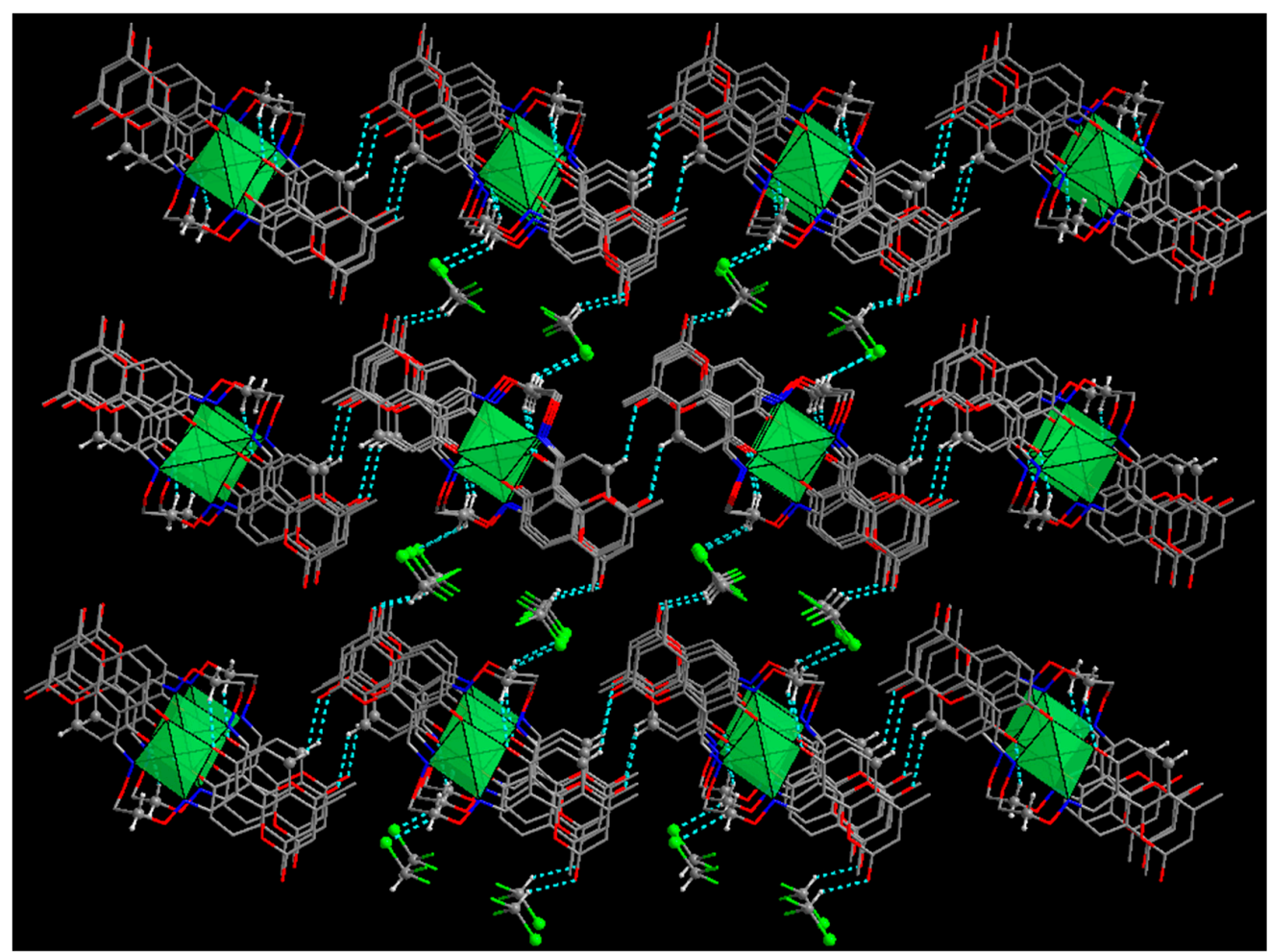

Figure 6. View of the three-dimensional supra-molecular structure of complex 1 showing the C-H $\cdots \mathrm{O}$, $\mathrm{C}-\mathrm{H} \cdots \mathrm{Cl}$ hydrogen bondings.

Table 5. Hydrogen bondings $\left(\AA,^{\circ}\right)$ for complex 1 .

\begin{tabular}{ccc}
\hline $\mathbf{D}-\mathbf{H} \cdot \mathbf{A}$ & $\mathbf{D} \cdot \mathbf{A}$ & $\mathbf{D}-\mathbf{H} \cdot \mathbf{A}$ \\
\hline $\mathrm{C} 10-\mathrm{H} 10 \cdot \mathrm{O} 4$ & $2.724(6)$ & 103 \\
$\mathrm{C} 13-\mathrm{H} 13 \cdot \mathrm{O} 7$ & $2.715(5)$ & 103 \\
$\mathrm{C} 12-\mathrm{H} 12 \mathrm{~B} \cdot \mathrm{O} 1$ & $3.495(6)$ & 156 \\
$\mathrm{C} 20-\mathrm{H} 20 \cdot \mathrm{O} 3$ & $3.284(6)$ & 133 \\
$\mathrm{C} 25-\mathrm{H} 25 \cdot \mathrm{O} 8$ & $3.071(7)$ & 141 \\
$\mathrm{C} 12-\mathrm{H} 12 \mathrm{~A} \cdot \mathrm{Cl1}$ & $3.561(6)$ & 136 \\
\hline
\end{tabular}

\subsection{Crystal Structure Description of Complex 2}

Complex 2 presents a symmetric mononuclear structure, crystallizes in the monoclinic system, space group $P 22_{1}$ /c, composes one $\mathrm{Co}$ (II) atom, one deprotonated (L) ${ }^{2-}$ unit, one coordinated methanol molecule and one crystalling chloroform molecule. Selected bond lengths and angles are listed in Table 6.

Table 6. Selected bond lengths $(\AA)$ and angles $\left(^{\circ}\right)$ for complex 2.

\begin{tabular}{cccc}
\hline \multicolumn{1}{c}{ Bond } & & & \\
\hline Co1-O1 & $2.008(3)$ & Co1-N1 & $2.014(3)$ \\
Co1-O6 & $1.926(3)$ & Co1-N2 & $2.150(3)$ \\
Co1-O9 & $2.039(3)$ & & \\
\hline Angles & & & \\
\hline O1-Co1-O9 & $90.67(12)$ & O6-Co1-N1 & $124.97(14)$ \\
O1-Co1-N1 & $88.52(12)$ & O6-Co1-N2 & $86.65(12)$ \\
O1-Co1-N2 & $178.25(13)$ & O9-Co1-N2 & $91.00(13)$ \\
O6-Co1-O1 & $93.23(11)$ & N1-Co1-O9 & $124.07(14)$ \\
O6-Co1-O9 & $110.91(13)$ & N1-Co1-N2 & $90.12(12)$ \\
\hline
\end{tabular}


As shown in Figure 7, the Co(II) atom is penta-coordinated by two oxime N (N1 and N2) and phenoxo $\mathrm{O}(\mathrm{O} 1$ and $\mathrm{O} 6)$ atoms from one deprotonated $(\mathrm{L})^{2-}$ unit, and one $\mathrm{O}(\mathrm{O} 9)$ atom from the coordinated methanol molecule (Figure 7a). The coordination around the $\mathrm{Co}(\mathrm{II})$ atom is depicted as a trigonal bipyramid [54], and the $\tau$ value was estimated to be $\tau=0.888$ (Figure $7 \mathrm{~b}$ ) [55]. The phenolic $\mathrm{O}(\mathrm{O} 6)$ atom and the oxime $\mathrm{N}(\mathrm{N} 1)$ atom of the $(\mathrm{L})^{2-}$ unit and one $\mathrm{O}(\mathrm{O} 9)$ atom of the coordinated methanol molecule compose together the basal plane (Co1-O6, 1.926(3); Co1-N1, 2.014(3) and Co1-O9, 2.039(3) $\AA$ ), and other phenolic O (O6) atom and oxime $\mathrm{N}(\mathrm{N} 1)$ atom of the $(\mathrm{L})^{2-}$ unit hold the axial positions (Co1-O1, 2.008(3) and Co1-N2, 2.150(3) $\AA$ ). The dihedral angles of the $\mathrm{N}_{2} \mathrm{O}_{2}$ basal plane and the benzene rings are $30.35(2)^{\circ}$ and $33.16(2)^{\circ}$, respectively, which defined as shown in Figure 8a. The dihedral angle of the planes N1-Co1-N2 and O1-Co1-O2 is 55.11(2) ${ }^{\circ}$ (Figure 8b) [56].

(a)

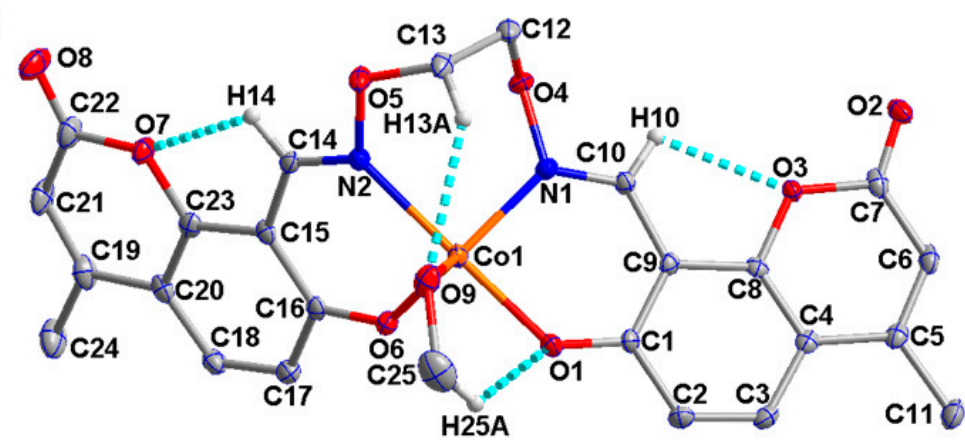

(b)

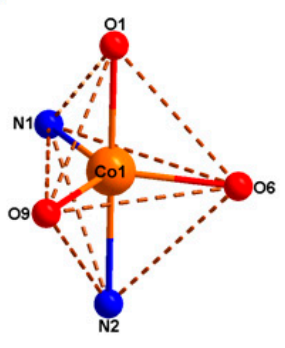

Figure 7. (a) X-ray crystal structure and atom numbering of complex 2 with $30 \%$ probability displacement ellipsoids; (b) Coordination polyhedron for Co(II) atom of complex 2.

(a)

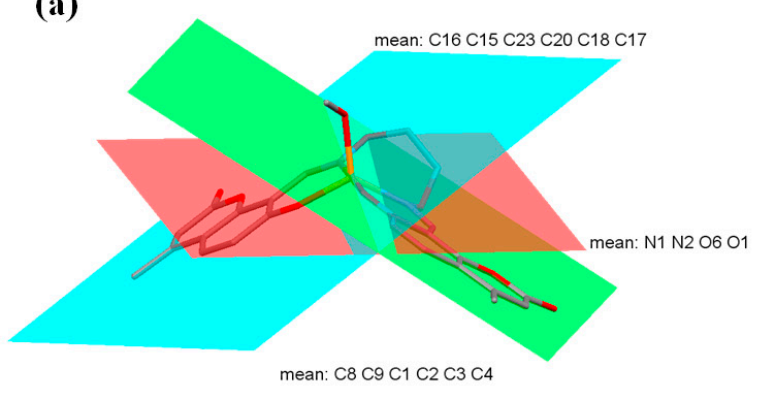

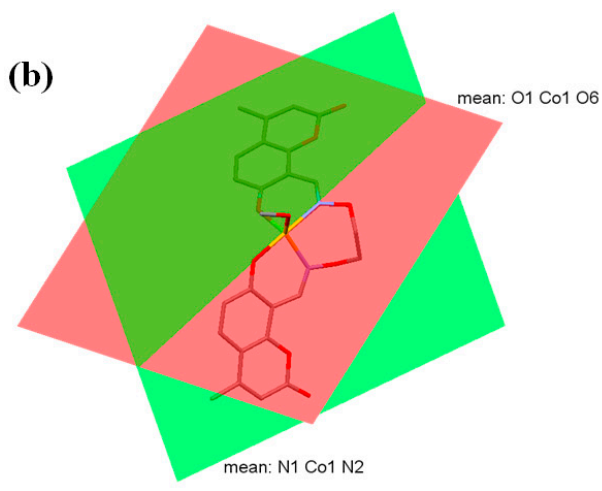

Figure 8. (a) View of the dihedral angles between the benzene rings and the $\mathrm{N}_{2} \mathrm{O}_{2}$ basal plane of complex 2; (b) View of the dihedral angles between the planes $\mathrm{CoN}_{2}$ and $\mathrm{CoO}_{2}$ of complex 2 .

As shown in Figure 9 and Table 7, the three-dimensional supra-molecular network of complex 2 is made up of two parts. The first part is linked by inter-molecular hydrogen bond interactions, and five pairs of inter-molecular hydrogen bonds, $\mathrm{C} 9-\mathrm{H} 9 \cdots \mathrm{O} 2, \mathrm{C} 6-\mathrm{H} 6 \cdots \mathrm{O} 6, \mathrm{C} 13-\mathrm{H} 13 \mathrm{~B} \cdots \mathrm{O} 2, \mathrm{C} 26-\mathrm{H} 26 \cdots \mathrm{O} 8$ and $\mathrm{C} 25-\mathrm{H} 25 \mathrm{C} \cdots \mathrm{Cl} 3$ are formed. The another part is made up of the $\mathrm{C}-\mathrm{Cl} \cdots \pi$ interactions. The $\mathrm{Cg} 6$ $\left(\mathrm{C}_{15}-\mathrm{C}_{16}-\mathrm{C}_{17}-\mathrm{C}_{18}-\mathrm{C}_{20}-\mathrm{C}_{23}\right)$ of phenyl as acceptors forms two stacking interactions with the protons (-C26Cl1 and $-\mathrm{C} 26 \mathrm{Cl} 2)$. The $\mathrm{Cg} 4\left(\mathrm{O}_{7}-\mathrm{C}_{19}-\mathrm{C}_{23}\right)$ of pyrone ring as acceptor forms one stacking interaction with - $\mathrm{C} 26 \mathrm{Cl} 2$. In addition, complex 2 molecules form a three-dimensional infinite structure by $\mathrm{O}-\mathrm{H} \cdots \mathrm{O}$, $\mathrm{C}-\mathrm{H} \cdots \mathrm{O}, \mathrm{C}-\mathrm{H} \cdots \mathrm{Cl}$ hydrogen bonds and $\mathrm{C}-\mathrm{Cl} \cdots \pi$ stacking interactions $[57,58]$. 


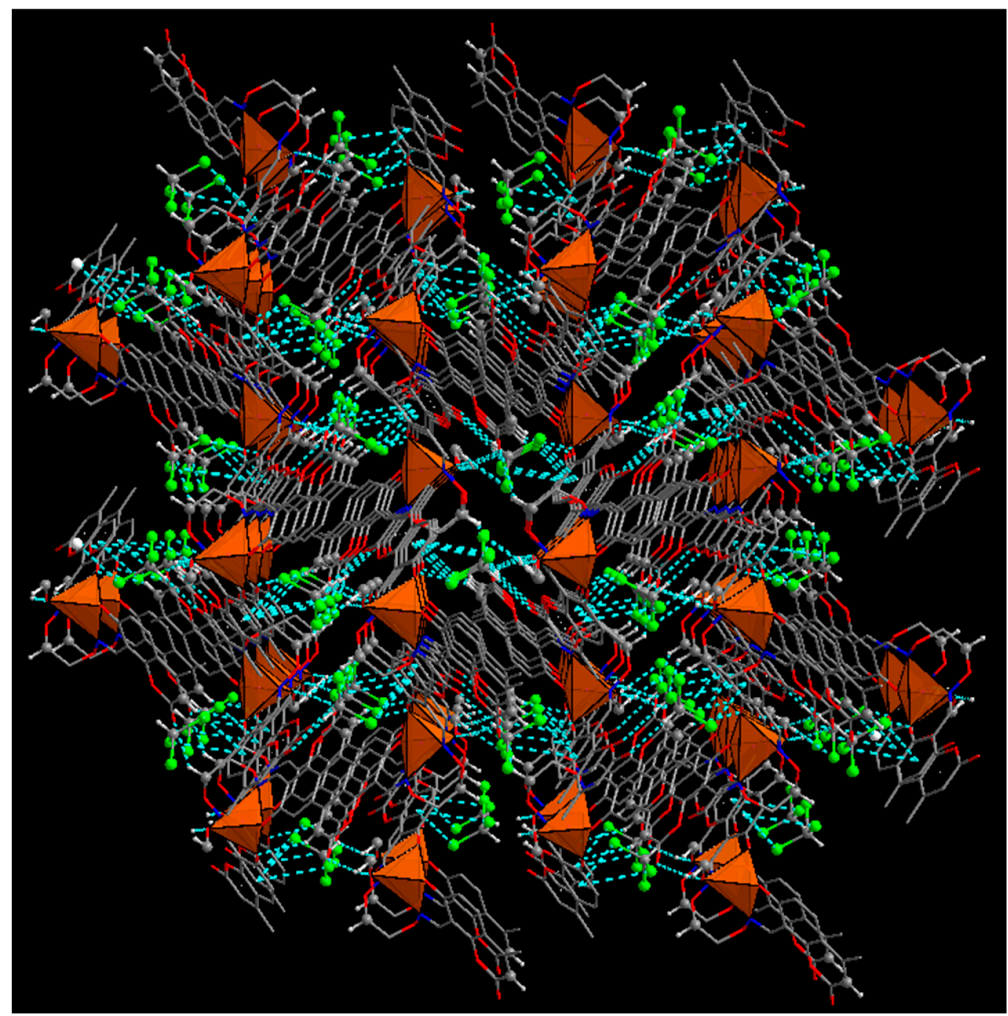

Figure 9. View of the three-dimensional supra-molecular structure of complex 2 exhibiting the $\mathrm{C}-\mathrm{H} \cdots \mathrm{O}$, $\mathrm{O}-\mathrm{H} \cdots \mathrm{O}, \mathrm{C}-\mathrm{H} \cdots \mathrm{Cl}$ hydrogen bondings and $\mathrm{C}-\mathrm{Cl} \cdots \pi$ stacking interactions.

Table 7. Hydrogen bondings $\left(\AA{ }^{\circ}\right)$ for complex 2.

\begin{tabular}{|c|c|c|c|c|}
\hline D-H $\cdots A$ & D..A & & D-H $\cdots A$ & \\
\hline $\mathrm{C} 10-\mathrm{H} 10 \cdots \mathrm{O} 3$ & $2.682(4)$ & & 104 & \\
\hline C13-H13A ‥ O9 & $3.433(6)$ & & 145 & \\
\hline C14-H14‥O7 & $2.712(5)$ & & 103 & \\
\hline $\mathrm{C} 25-\mathrm{H} 25 \mathrm{~A} \cdots \mathrm{O} 1$ & $3.041(7)$ & & 125 & \\
\hline O9-H9 ...O2 & $2.651(4)$ & & 166 & \\
\hline 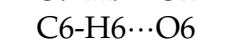 & $3.315(4)$ & & 139 & \\
\hline $\mathrm{C} 13-\mathrm{H} 13 \mathrm{~B} \cdots \mathrm{O} 2$ & $3.309(5)$ & & 134 & \\
\hline $\mathrm{C} 26-\mathrm{H} 26 \cdots \mathrm{O} 8$ & $3.146(6)$ & & 156 & \\
\hline $\mathrm{C} 25-\mathrm{H} 25 \mathrm{C} \cdots \mathrm{Cl} 3$ & $3.642(6)$ & & 159 & \\
\hline$D-X \cdots A$ & D-X & $\mathrm{X} \cdot \mathrm{A}$ & D..A & $D-X \cdots A$ \\
\hline $\mathrm{C} 26-\mathrm{Cl} 1 \cdots \mathrm{Cg} 6$ & $1.757(5)$ & 3.824 & $4.415(5)$ & 97.59 \\
\hline $\mathrm{C} 26-\mathrm{Cl} 2 \cdots \mathrm{Cg} 6$ & $1.757(5)$ & 3.849 & $4.415(5)$ & 96.78 \\
\hline $\mathrm{C} 26-\mathrm{Cl} 2 \cdots \mathrm{Cg} 4$ & $1.757(5)$ & 3.655 & $4.557(5)$ & 109.67 \\
\hline
\end{tabular}

Note: $\mathrm{Cg} 6=\mathrm{C}_{15}-\mathrm{C}_{16}-\mathrm{C}_{17}-\mathrm{C}_{18}-\mathrm{C}_{20}-\mathrm{C}_{23} ; \mathrm{Cg} 4=\mathrm{O}_{7}-\mathrm{C}_{19}-\mathrm{C}_{23}$.

\subsection{Crystal Structure Description of Complex 3}

As illustrated in Figure 10 and Table 8, complex 3 exhibits a symmetric trinuclear structure, crystallizes in the triclinic system, space group $P-1$, includes two completely deprotonated (L) ${ }^{2-}$ units, three $\mathrm{Ni}(\mathrm{II})$ atoms, two benzoates and two coordinated methanol molecules. 

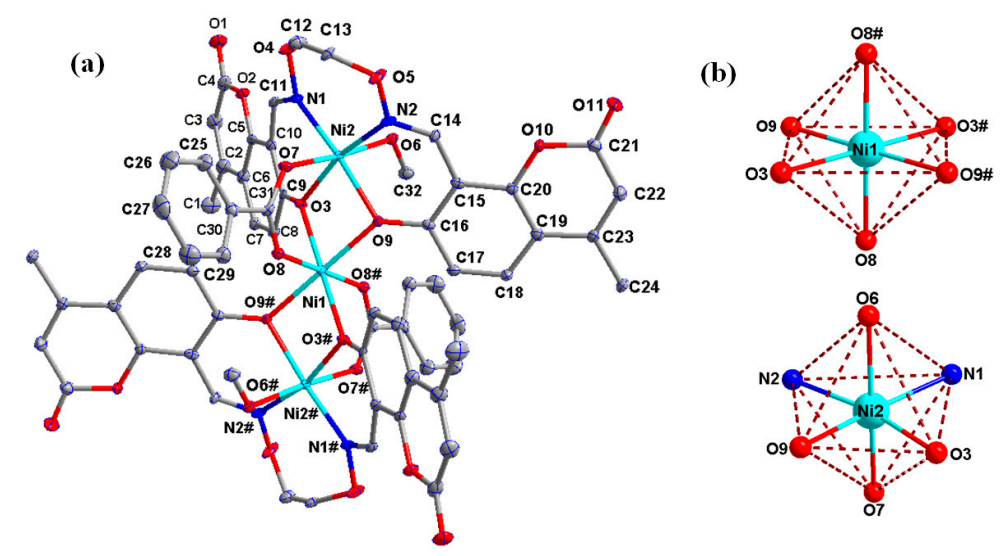

Figure 10. (a) X-ray crystal structure and atom numbering of complex 3 with $30 \%$ probability displacement ellipsoids; (b) Coordination polyhedrons for $\mathrm{Ni}(\mathrm{II})$ atoms of complex 3.

Table 8. Selected bond lengths $(\AA)$ and angles $\left(^{\circ}\right)$ for complex 3.

\begin{tabular}{cccc}
\hline Bond & & & \\
\hline Ni1-O3 & $2.082(3)$ & Ni2-O3 & $2.014(3)$ \\
Ni1-O3\# & $2.082(3)$ & Ni2-O6 & $2.150(3)$ \\
Ni1-O8 & $2.031(3)$ & Ni2-O7 & $2.018(3)$ \\
Ni1-O8\# & $2.031(3)$ & Ni2-O9 & $2.040(3)$ \\
Ni1-O9\# & $2.089(3)$ & Ni2-N1 & $2.068(4)$ \\
Ni1-O9 & $2.089(3)$ & Ni2-N2 & $2.069(4)$ \\
\hline Angles & & & \\
\hline O3-Ni1-O3\# & 180.0 & O3-Ni2-O6 & $93.13(12)$ \\
O3\#-Ni1-O9 & $101.51(11)$ & O3-Ni2-O9 & $80.97(11)$ \\
O3-Ni1-O9\# & $101.51(11)$ & O3-Ni2-N1 & $87.44(13)$ \\
O3-Ni1-O9 & $78.49(11)$ & O7-Ni2-O3 & $90.35(13)$ \\
O3\#-Ni1-O9\# & $78.49(11)$ & O7-Ni2-O6 & $175.38(11)$ \\
O8\#-Ni1-O3\# & $90.07(12)$ & O7-Ni2-O9 & $94.69(12)$ \\
O8\#-Ni1-O3 & $89.93(12)$ & O7-Ni2-N1 & $91.74(15)$ \\
O8-Ni1-O3\# & $89.93(12)$ & O7-Ni2-N2 & $90.06(15)$ \\
O8-Ni1-O3 & $90.07(12)$ & O9-Ni2-O6 & $88.86(12)$ \\
O8\#-Ni1-O8 & 180.0 & O9-Ni2-N1 & $166.76(13)$ \\
O8\#-Ni1-O9\# & $88.56(12)$ & O9-Ni2-N2 & $85.38(13)$ \\
O8-Ni1-O9 & $88.56(12)$ & N1-Ni2-O6 & $85.38(14)$ \\
O8\#-Ni1-O9 & $91.44(12)$ & N1-Ni2-N2 & $106.20(14)$ \\
O8-Ni1-O9\# & $91.44(12)$ & N2-Ni2-O6 & $87.29(15)$ \\
O9\#-Ni1-O9 & 180.0 & & \\
\hline
\end{tabular}

The terminal Ni2 atom is hexa-coordinated by two phenolic O (O3 and O9) and two oxime $\mathrm{N}$ (N1 and N2) atoms of the completely deprotonated (L) ${ }^{2-}$ moity, one $\mathrm{O}(\mathrm{O} 7)$ atom from the coordinated benzoate group and one $\mathrm{O}(\mathrm{O} 6)$ atom from the coordinated methanol molecule. The terminal Ni2 atom possesses a distorted octahedron geometry [59]. The two oxime $\mathrm{N}$ (N1 and N2) and phenolic $\mathrm{O}$ (O3 and O9) atoms are in mutually cis-positions. Then, the central Ni1 atom is completed by double $\mu_{2}$-phenoxo $\mathrm{O}$ (O3 and O9) atoms from two (L) ${ }^{2-}$ moities and two O (O8 and O8\#) atoms from two benzoate groups. Each of the benzoate groups bridges the central Ni1 and terminal Ni2 atoms in the syn-syn bridging mode, as a result the central Ni1 atom finally possesses an $\mathrm{O}_{2} \mathrm{O}_{2} \mathrm{O}_{2}$ coordination environment (Figure 10b) [59]. The dihedral angles between the benzene rings of (L) ${ }^{2-}$ moities and the $\mathrm{N}_{2} \mathrm{O}_{2}$ basal plane are $32.87(2)^{\circ}$ and $23.66(2)^{\circ}$, respectively, which defined as shown in Figure 11 a. The dihedral angle between the planes of N1-Ni2-N2 and O3-Ni2-O9 is 6.50(2) ${ }^{\circ}$ (Figure 11b) [59]. 
(a)

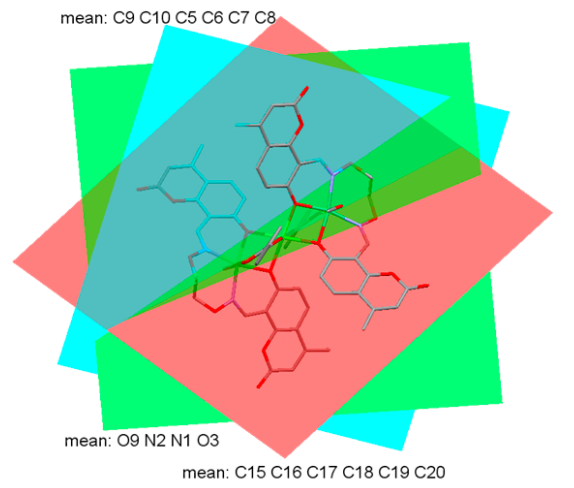

(b)

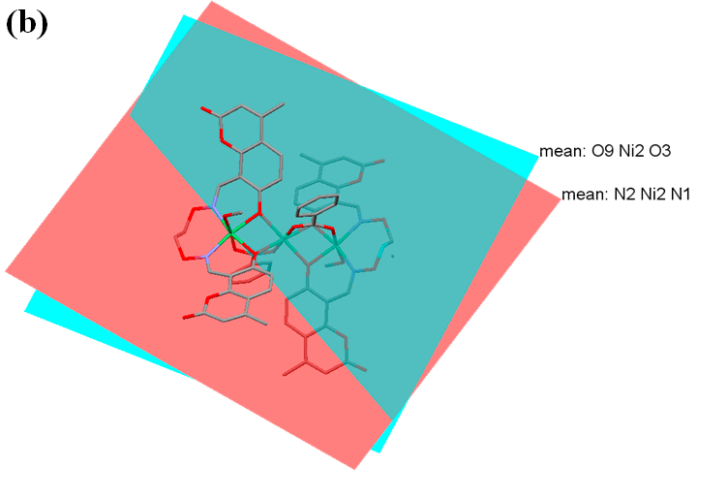

Figure 11. (a) View of the dihedral angles between the benzene rings and the $\mathrm{N}_{2} \mathrm{O}_{2}$ basal plane of complex 3; (b) View of the dihedral angles between the planes $\mathrm{NiN}_{2}$ and $\mathrm{NiO}_{2}$ of complex 3 .

As depicted in Figure 12 and Table 9, in complex 3, seven pairs of intra-molecular hydrogen

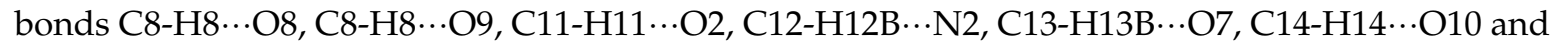
C32-H32C $\cdots$ O 8 are formed $[60,61]$. The protons $(-\mathrm{C} 11 \mathrm{H} 11)$ and $(-\mathrm{C} 14 \mathrm{H} 14)$ of $(\mathrm{L})^{2-}$ moities form hydrogen bondings with two ester $\mathrm{O}(\mathrm{O} 2$ and $\mathrm{O} 10)$ atoms of $(\mathrm{L})^{2-}$ moities, respectively. The proton $(-\mathrm{C} 12 \mathrm{H} 12 \mathrm{~B})$ from ethylenedioxime carbon atom of $(\mathrm{L})^{2-}$ moities forms hydrogen bonding with oxime $\mathrm{N}(\mathrm{N} 2)$ atom. The proton $(-\mathrm{C} 13 \mathrm{H} 13 \mathrm{~B})$ from ethylenedioxime carbon atom of the $(\mathrm{L})^{2-}$ moitie forms hydrogen bonding with carboxylate $\mathrm{O}(\mathrm{O} 7)$ atom of coordinated benzoate group. The proton (-C32H32C) from coordinated methanol molecule form hydrogen bonding with $\mathrm{O}(\mathrm{O} 8)$ atom of coordinated benzoate group. The proton $(-\mathrm{C} 8 \mathrm{H} 8)$ of the $(\mathrm{L})^{2-}$ moity forms hydrogen bonds with phenoxo $\mathrm{O}(\mathrm{O} 9)$ atom of $(\mathrm{L})^{2-}$ moity and carboxylate $\mathrm{O}(\mathrm{O} 8)$ atom of coordinated benzoate group, respectively $[62,63]$.

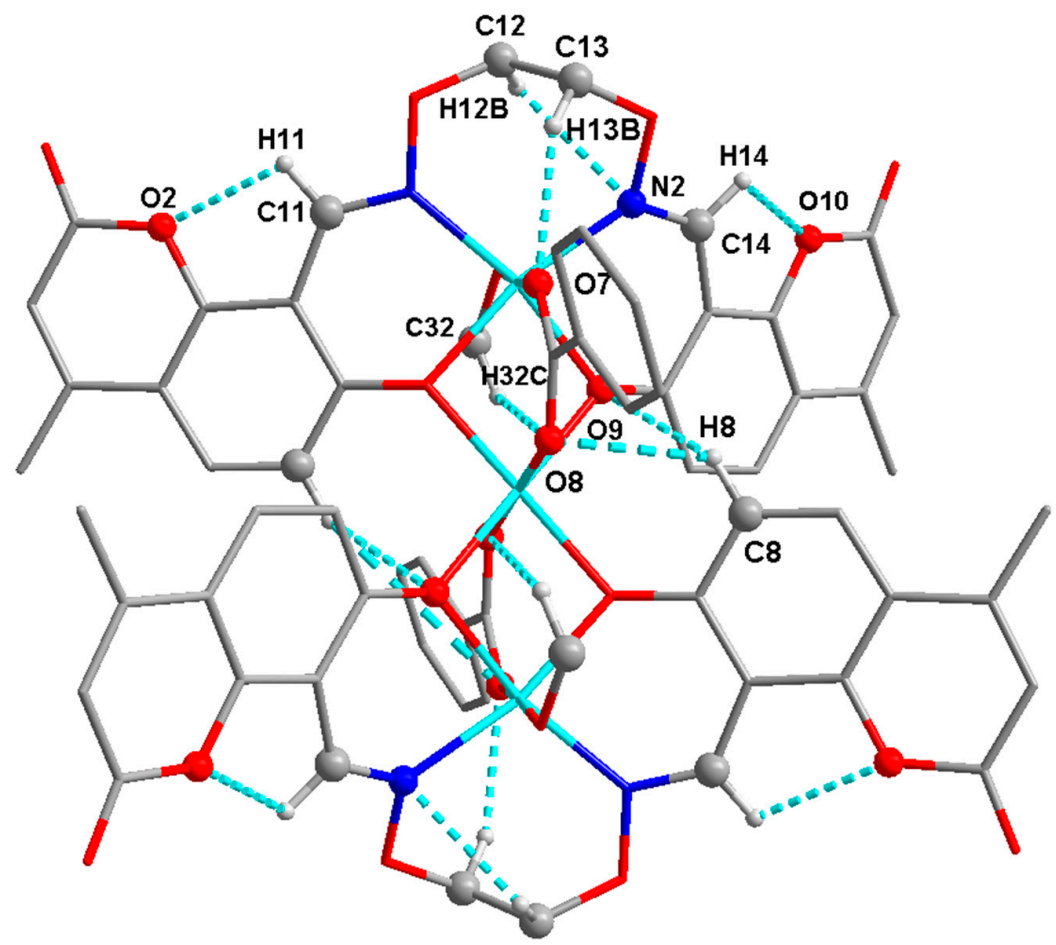

Figure 12. Intra-molecular $\mathrm{C}-\mathrm{H} \cdots \mathrm{O}$ and $\mathrm{C}-\mathrm{H} \cdots \mathrm{N}$ hydrogen bonds of complex 3. 
Table 9. Hydrogen bondings $\left(\AA,^{\circ}\right)$ for complex 3 .

\begin{tabular}{|c|c|c|}
\hline D-H $\cdots A$ & $\mathrm{D} \cdots \mathrm{A}$ & $\mathrm{D}-\mathrm{H} \cdots \mathrm{A}$ \\
\hline $\mathrm{C} 8-\mathrm{H} 8 \cdots \mathrm{O} 8$ & $3.176(6)$ & 122 \\
\hline 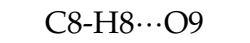 & $3.289(5)$ & 133 \\
\hline $\mathrm{C} 11-\mathrm{H} 11 \cdots \mathrm{O} 2$ & $2.661(6)$ & 103 \\
\hline $\mathrm{C} 12-\mathrm{H} 12 \mathrm{~B} \cdots \mathrm{N} 2$ & $2.878(9)$ & 102 \\
\hline C13-H13B ‥O7 & $3.110(8)$ & 142 \\
\hline $\mathrm{C} 14-\mathrm{H} 14 \cdots \mathrm{O} 10$ & $2.673(6)$ & 101 \\
\hline C32-H32C $\cdots \mathrm{O} 8$ & $3.362(6)$ & 155 \\
\hline 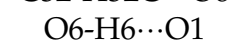 & $2.741(5)$ & 164 \\
\hline C12-H12A …O11 & $3.180(8)$ & 154 \\
\hline
\end{tabular}

As illustrated in Figure 13, two pairs of inter-molecular hydrogen bondings, O6-H6 ...O1 and $\mathrm{C} 12-\mathrm{H} 12 \mathrm{~A} \cdots \mathrm{O} 11$ are formed. The proton $(-\mathrm{C} 12 \mathrm{H} 12 \mathrm{~A})$ of the $\left((\mathrm{L})^{2-}\right.$ moity forms hydrogen bondings with the $\mathrm{O}(\mathrm{O} 11)$ atom of four adjacent complex 3 molecules. Meanwhile, the proton (-O6H6) of the coordinated methanol molecule forms hydrogen bondings with the $\mathrm{O}(\mathrm{O} 1)$ atom from the $(\mathrm{L})^{2-}$ moity of four adjacent complex 3 molecules. The space skeleton of complex 3 possesses a two-dimensional supra-molecular structure by the hydrogen bonding interactions [64].

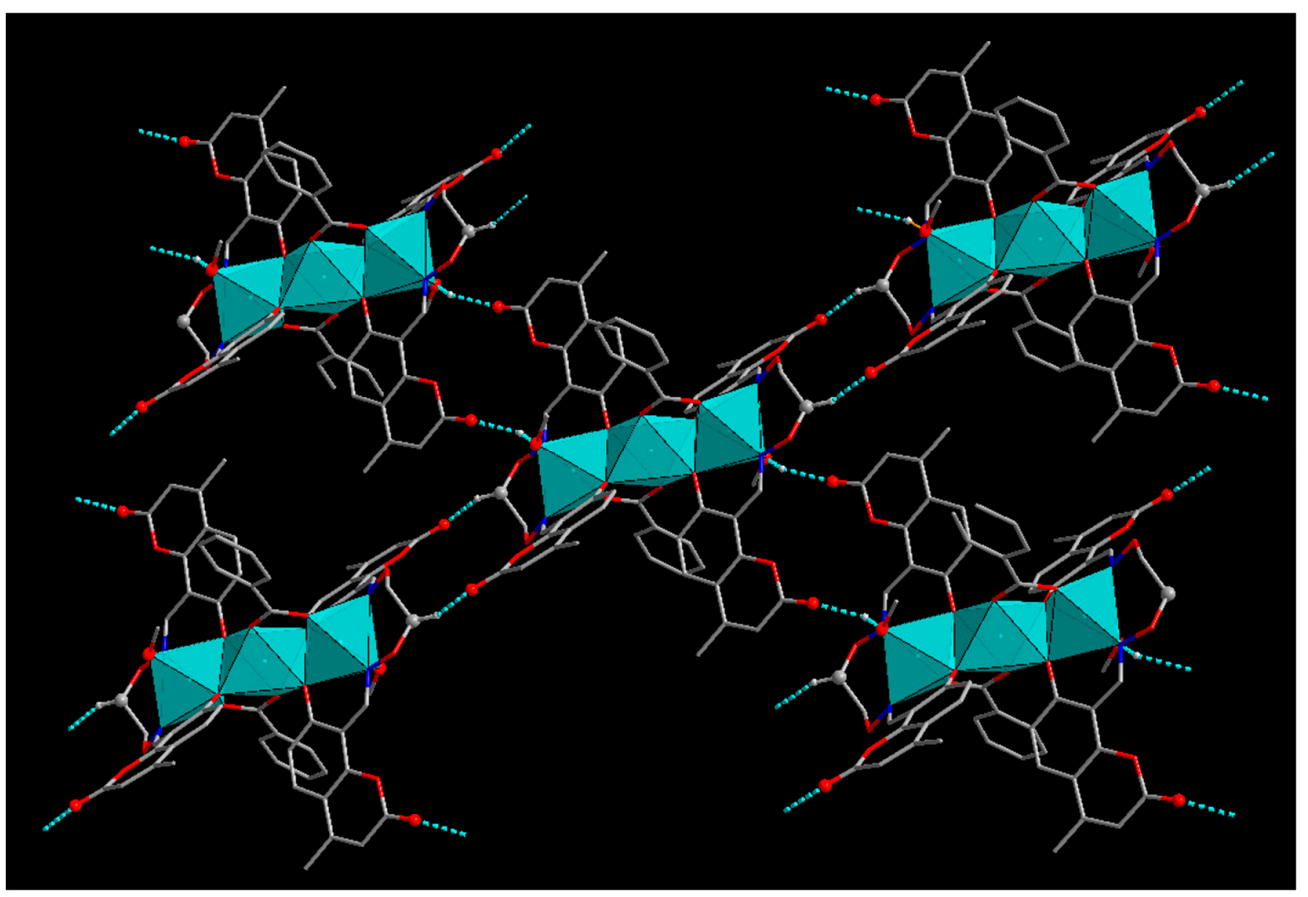

Figure 13. View of the two-dimensional supra-molecular structure of complex 3 exhibiting the $\mathrm{O}-\mathrm{H} \cdots \mathrm{O}$, $\mathrm{C}-\mathrm{H}$... O hydrogen bonding interactions.

Complexes 1, 2 and 3 with a coumarin-containing Salamo-type ligand $\mathrm{H}_{2} \mathrm{~L}$ have been synthesized, and have different structures depending on the anions and cations used. In complexes 1, 2 and 3, the metal atom located at the Salamo $\mathrm{N}_{2} \mathrm{O}_{2}$ unit is tetra-, penta- and hexa-coordinated, respectively. As widely known, the coordination number of $\mathrm{Cu}$ (II) atom is generally four or five in Salamo-type $\mathrm{Cu}$ (II) complexes and the coordination geometry around $\mathrm{Cu}$ (II) atom is planar quadrilateral, tetrahedron or tetragonal pyramid $[26,37,49,51]$. In complex $\mathbf{1}$, the coordination number of $\mathrm{Cu}(\mathrm{II})$ atom is four, the anions and the solvent molecules were not involved in the coordination. The coordination number of $\mathrm{Co}(\mathrm{II})$ atom is generally six, and the coordination geometry around Co(II) atom is octahedron $[47,56,63,65]$. While in complex 2 , the methanol molecule was involved in the coordination 
forming a mono-nuclear $\mathrm{Co}$ (II) complex. The coordination geometry around $\mathrm{Co}(\mathrm{II})$ atom is trigonal bipyramid, which is rare in the previously reported Salamo-type Co(II) complexes. In complex 3, both of the anions and the solvent molecules were involved in the coordination, this coordination pattern is frequently appeared in the Salamo-type trinuclear $\mathrm{Ni}$ (II) complexes, in which the three $\mathrm{Ni}$ (II) atoms are all hexa-coordinated with slightly distorted octahedral geometries [12,31,44,59], but the research on the Salamo-type trinuclear Ni(II) complex contained benzoate ligands is reported firstly.

\subsection{Antimicobial Activities}

Bacteriostasis tests on common bacteria, such as E. coli and S. aureus, were carried out by the punch method. A small amount $(0.1 \mathrm{~mL})$ of a fresh overnight bacterial suspension was added into autoclaved LB (lysogeny broth) agar, then the agar was poured into sterile dishes. The concentration of the test compounds were $0.6,1.2$ and $2.4 \mathrm{mg} / \mathrm{mL}$. $70 \mu \mathrm{L}$ of samples were added into a burrowed hole measuring $5 \mathrm{~mm}$ in diameter with transfer liquid gun when the medium underwent solidification $[65,66]$.

As shown in Figures 14 and 15, the zones of DMF, metal salts, $\mathrm{H}_{2} \mathrm{~L}$ and complexes $\mathbf{1}, \mathbf{2}$ and 3 have apparent differences in antibacterial activity among two kinds of bacteria. The complexes 1, 2 and 3 displayed more enhanced antimicrobial activities than $\mathrm{H}_{2} \mathrm{~L}$ under the same conditions $(2.5 \mathrm{mg} / \mathrm{mL})$, and the DMF and the metal salts also have a weak biological activity. Moreover, E. coli shows stronger antibacterial activity, whereas $S$. aureus possesses weaker antibacterial activity. This increase in the antibacterial activities of complexes 1, $\mathbf{2}$ and $\mathbf{3}$ were accompanied with an increase in concentration and can be explained on the basis of the chelation theory $[65,66]$. Chelation reduces the polarity of the metal atom mainly due to partial share of positive charge of metal atom with donor groups and possible delocalization of $\pi$-electron within the whole chelate ring. Further, it enhances the lipophilic character of the central atom [66].

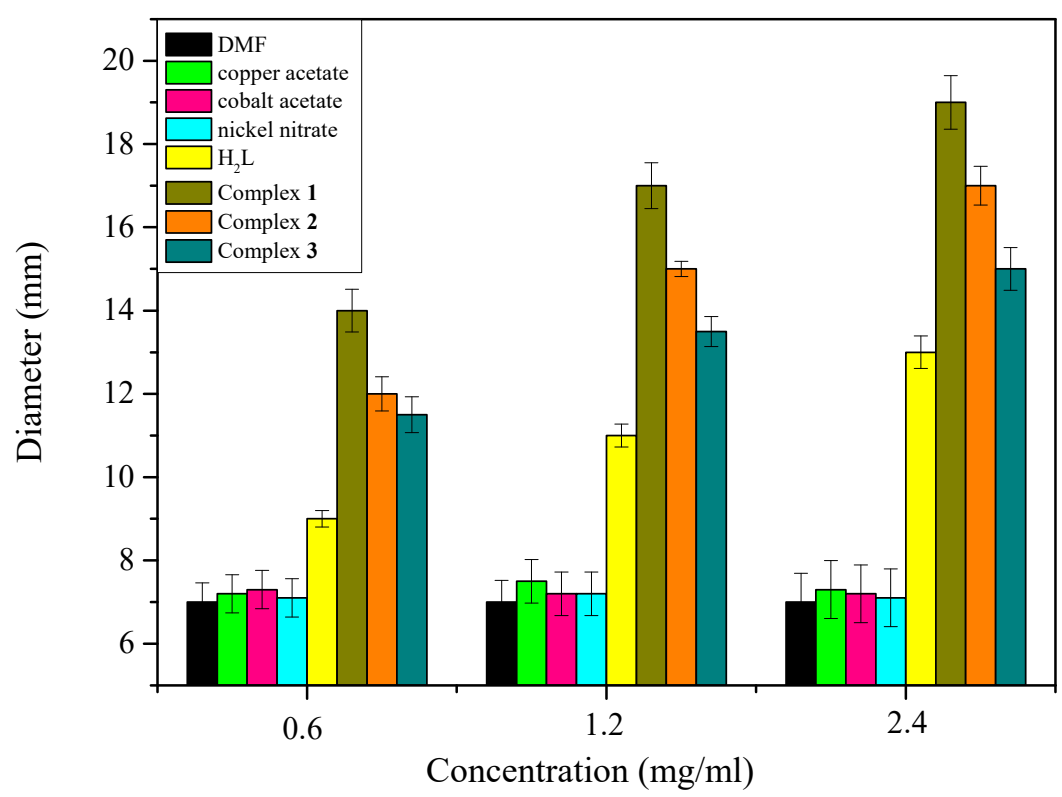

Figure 14. The diameter of inhibition zones of E. coli in different concentrations. 


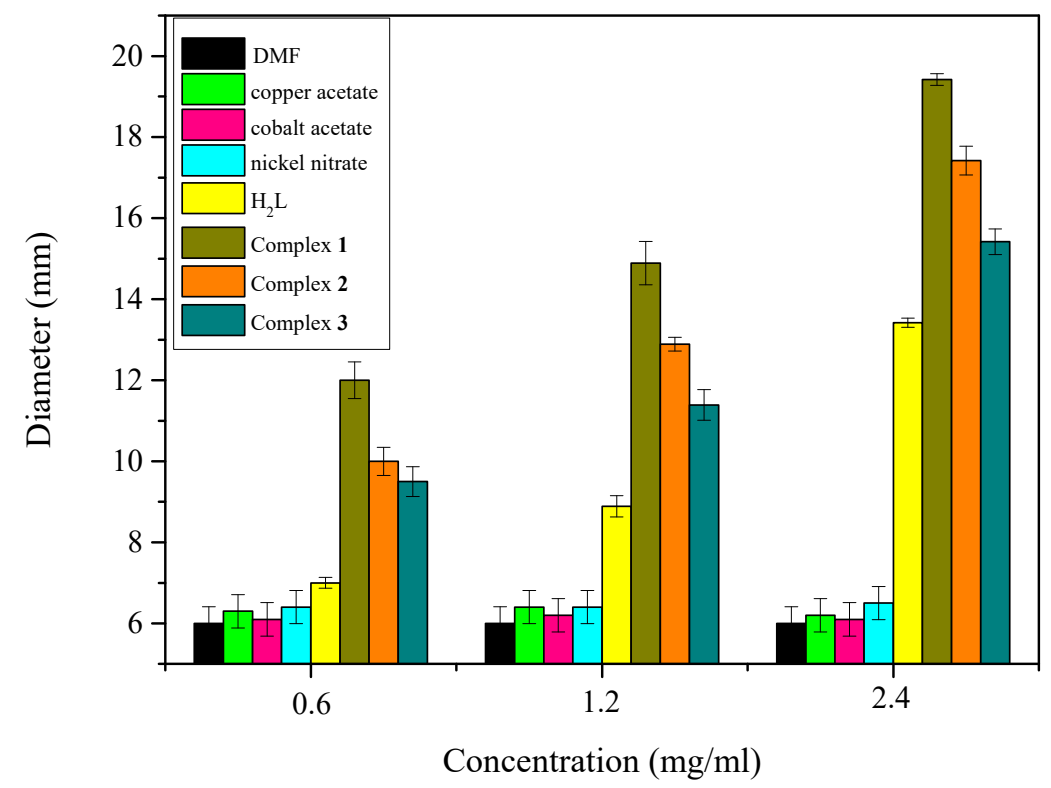

Figure 15. The diameter of inhibition zones of S. aureus in different concentrations.

\section{Conclusions}

In summary, three newly designed complexes $[\mathrm{Cu}(\mathrm{L})] \cdot \mathrm{CHCl}_{3}(\mathbf{1}),[\mathrm{Co}(\mathrm{L})(\mathrm{MeOH})] \cdot \mathrm{CHCl}_{3}(\mathbf{2})$ and $\left[\{\mathrm{Ni}(\mathrm{L})(\mathrm{MeOH})(\mathrm{PhCOO})\}_{2} \mathrm{Ni}\right](3)$ derived from a Salamo-type coumarin-containing ligand $\left(\mathrm{H}_{2} \mathrm{~L}\right)$ have been successfully prepared and well characterized. For the central metals, the $\mathrm{Cu}(\mathrm{II})$ atom of complex $\mathbf{1}$ is tetra-coordinated and the $\mathrm{Co}(\mathrm{II})$ atom of complex 2 is penta-coordinated with trigonal-bipyramidal geometry, and the $\mathrm{Ni}(\mathrm{II})$ atoms of complex 3 are hexa-coordinated possessing slightly distorted octahedral geometries. The complexes $\mathbf{1}$ and $\mathbf{2}$ are both possess the three-dimensional supra-molecular structures by abundant noncovalent interactions. But complex 3 is formed a two-dimensional supra-molecular structure by intra-molecular hydrogen bonds. Furthermore, the antimicrobial and fluorescence properties of $\mathrm{H}_{2} \mathrm{~L}$ and complexes 1, 2 and 3 were also studied.

Acknowledgments: This work was supported by the National Natural Science Foundation of China (21761018) and the Program for Excellent Team of Scientific Research in Lanzhou Jiaotong University (201706), which is gratefully acknowledged.

Author Contributions: W.-K.D. supervised the project and contributed materials/reagents/analysis tools; C.L. and F.W. performed the experiments; W.-K.D., L.G. wrote the manuscript.

Conflicts of Interest: The authors declare no conflict of interest.

\section{References}

1. Zhao, L.; Dang, X.T.; Chen, Q.; Zhao, J.X.; Wang, L. Synthesis, crystal structure and spectral properties of a 2D supramolecular copper(II) complex with 1-(4-\{[(E)-3-ethoxyl-2-hydroxybenzylidene]amino\}phenyl)ethanone oxime. Synth. React. Inorg. Met.-Org. Nano-Met. Chem. 2013, 43, 1241-1246. [CrossRef]

2. Wu, H.L.; Pan, G.L.; Bai, Y.C.; Wang, H.; Kong, J.; Shi, F.; Zhang, Y.H.; Wang, X.L. Preparation, structure, DNA-binding properties, and antioxidant activities of a homodinuclear erbium(III) complex with a pentadentate Schiff base ligand. J. Chem. Res. 2014, 38, 211-217. [CrossRef]

3. Sun, Y.X.; Zhang, S.T.; Ren, Z.L.; Dong, X.Y.; Wang, L. Synthesis, characterization, and crystal structure of a new supramolecular $\mathrm{Cd}^{\mathrm{II}}$ complex with halogen-substituted salen-type bisoxime. Synth. React. Inorg. Met.-Org. Nano-Met. Chem. 2013, 43, 995-1000. [CrossRef]

4. Song, X.Q.; Liu, P.P.; Liu, Y.A.; Zhou, J.J.; Wang, X.L. Two dodecanuclear heterometallic $\left[Z_{6} \operatorname{Ln}_{6}\right]$ clusters constructed by a multidentate salicylamide salen-like ligand: Synthesis, structure, luminescence and magnetic properties. Dalton Trans. 2016, 45, 8154-8163. [CrossRef] [PubMed] 
5. Xu, L.; Zhu, L.C.; Ma, J.C.; Zhang, Y.; Zhang, J.; Dong, W.K. Syntheses, structures and spectral properties of mononuclear $\mathrm{Cu}^{\mathrm{II}}$ and dimeric $\mathrm{Zn}^{\mathrm{II}}$ complexes an asymmetric Salamo-type $\mathrm{N}_{2} \mathrm{O}_{2}$ ligand. Zeitschrift für Anorganische und Allgemeine Chemie 2015, 641, 2520-2524. [CrossRef]

6. Wang, P.; Zhao, L. Synthesis and crystal structure of supramolecular copper(II) complex $\mathrm{N}_{2} \mathrm{O}_{2}$ coordination Sphere. Asian J. Chem. 2015, 4, 1424-1426. [CrossRef]

7. Sun, Y.X.; Wang, L.; Dong, X.Y.; Ren, Z.L.; Meng, W.S. Synthesis, characterization, and crystal structure of a supramolecular $\mathrm{Co}^{\mathrm{II}}$ complex containing Salen-type bisoxime. Synth. React. Inorg. Met-Org. Nano-Met. Chem. 2013, 43, 599-603. [CrossRef]

8. Wu, H.L.; Bai, Y.C.; Zhang, Y.H.; Pan, G.L.; Kong, J.; Shi, F.; Wang, X.L. Two lanthanide(III) complexes the schiff base N,N-Bis(salicylidene)-1,5-diamino-3-oxapentane: Synthesis, characterization, DNA-binding properties, and antioxidation. Zeitschrift für Anorganische und Allgemeine Chemie 2014, 640, 2062-2071. [CrossRef]

9. Wu, H.L.; Bai, Y.; Yuan, J.K.; Wang, H.; Pan, G.L.; Fan, X.Y.; Kong, J. A zinc(II) complex with tris(2-(N-methyl)benzimidazlylmethyl)amine and salicylate: Synthesis, crystal structure, and DNA-binding. J. Coord. Chem. 2012, 65, 2839-2851. [CrossRef]

10. Chen, C.Y.; Zhang, J.W.; Zhang, Y.H.; Yang, Z.H.; Wu, H.L. Gadolinium(III) and dysprosium(III) complexes with a Schiff base bis( $N$-salicylidene)-3-oxapentane-1,5-diamine: Synthesis, characterization, antioxidation, and DNA-binding studies. J. Coord. Chem. 2015, 68, 1054-1071. [CrossRef]

11. Wang, F.; Gao, L.; Zhao, Q.; Zhang, Y.; Dong, W.K.; Ding, Y.J. A highly selective fluorescent chemosensor for $\mathrm{CN}^{-}$a novel bis(salamo)-type tetraoxime ligand. Spectrochim. Acta Part A 2018, 190, 111-115. [CrossRef] [PubMed]

12. Dong, X.Y.; Li, X.Y.; Liu, L.Z.; Zhang, H.; Ding, Y.J.; Dong, W.K. Tri- and hexanuclear heterometallic $\mathrm{Ni}(\mathrm{II})-\mathrm{M}(\mathrm{II})(\mathrm{M}=\mathrm{Ca}, \mathrm{Sr}$ and Ba) bis(salamo)-type complexes: Synthesis, structure and fluorescence properties. RSC Adv. 2017, 7, 48394-48403. [CrossRef]

13. Wu, H.L.; Wang, C.P.; Wang, F.; Peng, H.P.; Zhang, H.; Bai, Y.C. A new manganese(III) complex from bis(5-methylsalicylaldehyde)-3-oxapentane-1,5-diamine: Synthesis, characterization, antioxidant activity and luminescence. J. Chin. Chem. Soc. 2015, 62, 1028-1034. [CrossRef]

14. Dong, W.K.; Ma, J.C.; Zhu, L.C.; Zhang, Y. Self-assembled zinc(II)-lanthanide(III) heteromultinuclear complexes constructed from 3-MeOsalamo ligand: Syntheses, structures and luminescent properties. Cryst. Growth Des. 2016, 16, 6903-6914. [CrossRef]

15. Song, X.Q.; Peng, Y.J.; Chen, G.Q.; Wang, X.R.; Liu, P.P.; Xu, W.Y. Substituted group-directed assembly of $\mathrm{Zn}$ (II) coordination complexes two new structural related pyrazolone Salen ligands: Syntheses, structures and fluorescence properties. Inorg. Chim. Acta 2015, 427, 13-21. [CrossRef]

16. Dong, W.K.; Zhang, F.; Li, N.; Xu, L.; Zhang, Y.; Zhang, J.; Zhu, L.C. Trinuclear cobalt(II) and zinc(II) salamo-type complexes: Syntheses, crystal structures, and fluorescent properties. Zeitschrift für Anorganische und Allgemeine Chemie 2016, 642, 532-538. [CrossRef]

17. Song, X.Q.; Cheng, G.Q.; Liu, Y.A. Enhanced $\mathrm{Tb}(\mathrm{III})$ luminescence by $\mathrm{d}^{10}$ transition metal coordination. Inorg. Chim. Acta 2016, 450, 386-394. [CrossRef]

18. Dong, W.K.; Ma, J.C.; Zhu, L.C.; Zhang, Y. Nine self-assembled nickel(II)-lanthanide(III) heterometallic complexes constructed from a Salamo-type bisoxime and bearing N- or O-donor auxiliary ligand: Syntheses, structures and magnetic properties. New J. Chem. 2016, 40, 6998-7010. [CrossRef]

19. Song, X.Q.; Liu, P.P.; Xiao, Z.R.; Li, X.; Liu, Y.A. Four polynuclear complexes a versatile salicylamide salen-like ligand: Synthesis, structural variations and magnetic properties. Inorg. Chim. Acta 2015, 438, 232-244. [CrossRef]

20. Dong, W.K.; Ma, J.C.; Dong, Y.J.; Zhu, L.C.; Zhang, Y. Di-and tetranuclear heterometallic 3d-4f cobalt(II)-lanthanide(III) complexes derived from a hexadentate bisoxime: Syntheses, structures and magnetic properties. Polyhedron 2016, 115, 228-235. [CrossRef]

21. Liu, P.P.; Wang, C.Y.; Zhang, M.; Song, X.Q. Pentanuclear sandwich-type Zn ${ }^{\mathrm{II}}$-Ln ${ }^{\mathrm{III}}$ clusters a new Salen-like salicylamide ligand: Structure, near-infrared emission and magnetic properties. Polyhedron 2017, 129, 133-140. [CrossRef]

22. Wu, H.L.; Pan, G.L.; Wang, H.; Wang, X.L.; Bai, Y.C.; Zhang, Y.H. Study on synthesis, crystal structure, antioxidant and DNA-binding of mono-, di- and poly-nuclear lanthanides complexes with bis(N-salicylidene)-3-oxapentane-1,5-diamine. J. Photochem. Photobiol. B Biol. 2014, 135, 33-43. [CrossRef] [PubMed] 
23. Dong, W.K.; Zhang, J.; Zhang, Y.; Li, N. Novel multinuclear transition metal(II) complexes an asymmetric Salamo-type ligand: Syntheses, structure characterizations and fluorescent properties. Inorg. Chim. Acta 2016, 444, 95-102. [CrossRef]

24. Dong, Y.J.; Li, X.L.; Zhang, Y.; Dong, W.K. A highly selective visual and fluorescent sensor for $\mathrm{Pb}^{2+}$ and $\mathrm{Zn}^{2+}$ and crystal structure of $\mathrm{Cu}^{2+}$ complex-on a novel single-armed Salamo-type bisoxime. Supramol. Chem. 2017, 29, 518-527. [CrossRef]

25. Sun, Y.X.; Xu, L.; Zhao, T.H.; Liu, S.H.; Liu, G.H.; Dong, X.T. Synthesis and crystal structure of a 3D supramolecular copper(II) complex with 1-(3-\{[(E)-3-bromo-5-chloro-2-hydroxybenzylidene]amino\}phenyl) ethanone oxime. Synth. React. Inorg. Met.-Org. Nano-Met. Chem. 2013, 43, 509-513. [CrossRef]

26. Dong, W.K.; Wang, Z.K.; Li, G.; Zhao, M.M.; Dong, X.Y.; Liu, S.H. Syntheses, crystal structures, and properties of a Salamo-type tetradentate chelating ligand and its pentacoordinated copper(II) complex. Zeitschrift für Anorganische und Allgemeine Chemie 2013, 639, 2263-2268. [CrossRef]

27. Akine, S.; Dong, W.K.; Nabeshima, T. Octanuclear zinc(II) and cobalt(II) clusters produced by cooperative tetrameric assembling of oxime chelate ligands. Inorg. Chem. 2006, 454, 677-4684. [CrossRef] [PubMed]

28. Dong, W.K.; Zhang, X.Y.; Zhao, M.M.; Li, G.; Dong, X.Y. Syntheses and crystal structures of 5-Methoxy-6'-hydroxy-2,2'-[ethylenedioxybis(nitrilomethylidyne)]diphenol and its tetranuclear zinc(II) complex. Chin. J. Inorg. Chem. 2014, 30, 710-716.

29. Akine, S.; Taniguchi, T.; Dong, W.K.; Masubuchi, S.; Nabeshima, T. Oxime-Based Salen-Type Tetradentate Ligands with High Stability against Imine Metathesis Reaction. J. Org. Chem. 2005, 70, 1704-1711. [CrossRef] [PubMed]

30. Dong, W.K.; Li, X.L.; Wang, L.; Zhang, Y.; Ding, Y.J. A new application of Salamo-type bisoximes: As a relay-sensor for $\mathrm{Zn}^{2+} / \mathrm{Cu}^{2+}$ and its novel complexes for successive sensing of $\mathrm{H}^{+} / \mathrm{OH}^{-}$. Sens. Actuators B Chem. 2016, 229, 370-378. [CrossRef]

31. Wang, L.; Ma, J.C.; Dong, W.K.; Zhu, L.C.; Zhang, Y. A novel Self-assembled nickel(II)-cerium(III) heterotetranuclear dimer constructed from $\mathrm{N}_{2} \mathrm{O}_{2}$-type bisoxime and terephthalic acid: Synthesis, structure and photophysical properties. Zeitschrift für Anorganische und Allgemeine Chemie 2016, 642, 834-839. [CrossRef]

32. Dong, W.K.; Li, G.; Wang, Z.K.; Dong, X.Y. A novel trinuclear cobalt(II) complex derived from an asymmetric Salamo-type $\mathrm{N}_{2} \mathrm{O}_{3}$ bisoxime chelate ligand: Synthesis, structure and optical properties. Spectrochim. Acta Part A 2014, 133, 340-347. [CrossRef] [PubMed]

33. Akine, S.; Morita, Y.; Utsuno, F.; Nabeshima, T. Multiple folding structures mediated by metal coordination of acyclic multidentate ligand. Inorg. Chem. 2009, 48, 10670-10678. [CrossRef] [PubMed]

34. Wang, B.J.; Dong, W.K.; Zhang, Y.; Akogun, S.F. A novel relay-sensor for highly sensitive and selective detection of $\mathrm{Zn}^{2+} / \mathrm{Pic}^{-}$and fluorescence on/off switch response of $\mathrm{H}^{+} / \mathrm{OH}^{-}$. Sens. Actuators B Chem. 2017, 247, 254-264. [CrossRef]

35. Dong, W.K.; Zhang, L.S.; Sun, Y.X.; Zhao, M.M.; Li, G.; Dong, X.Y. Synthesis, crystal structure and spectroscopic properties of a supramolecular zinc(II) complex with $\mathrm{N}_{2} \mathrm{O}_{2}$ coordination sphere. Spectrochim. Acta Part A 2014, 121, 324-329. [CrossRef] [PubMed]

36. Hao, J.; Li, L.H.; Zhang, J.T.; Akogun, S.F.; Wang, L.; Dong, W.K. Four homo- and hetero-bismetallic 3d/3d-2s complexes constructed from a naphthalenediol-based acyclic bis(salamo)-type tetraoxime ligand. Polyhedron 2017, 134, 1-10. [CrossRef]

37. Chen, L.; Dong, W.K.; Zhang, H.; Zhang, Y.; Sun, Y.X. Structural variation and luminescence properties of triand dinuclear $\mathrm{Cu}^{\mathrm{II}}$ and $\mathrm{Zn}^{\mathrm{II}}$ complexes constructed from a naphthalenediol-based bis(Salamo)-type ligand. Cryst. Growth Des. 2017, 17, 3636-3648. [CrossRef]

38. Dong, W.K.; Ma, J.C.; Dong, Y.J.; Zhao, L.; Zhu, L.C.; Sun, Y.X.; Zhang, Y. Two hetero-trinuclear Zn(II)-M(II) $(\mathrm{M}=\mathrm{Sr}, \mathrm{Ba})$ complexes metallohost of mononuclear Zn(II) complex: Syntheses, structures and fluorescence properties. J. Coord. Chem. 2016, 69, 3231-3241. [CrossRef]

39. Dong, Y.J.; Dong, X.Y.; Dong, W.K.; Zhang, Y.; Zhang, L.S. Three asymmetric Salamo-type copper(II) and cobalt(II) complexes: Syntheses, structures, fluorescent properties. Polyhedron 2017, 123, 305-315. [CrossRef]

40. Dong, Y.; Li, F.J.; Jiang, X.X.; Song, F.Y.; Cheng, Y.X.; Zhu, C.J. Na ${ }^{+}$triggered fluorescence sensors for $\mathrm{Mg}^{2+}$ detection a coumarin salen moiety. Org. Lett. 2011, 9, 2252-2255. [CrossRef] [PubMed]

41. Madison, W.I. SAINT-Plus, Bruker Analytical X-ray System; Bruker: Billerica, MA, USA, 1999.

42. Sheldrick, G.M. SADABS, Program for Empirical Absorption Correction of Area Detector Data; University of Gottingen: Gottingen, Germany, 1996. 
43. Sheldrick, G.M. SHELXS-97, Program for the Solution and the Refinement of Crystal Structures; University of Gottingen: Gottingen, Germany, 1997.

44. Gao, L.; Wang, F.; Zhao, Q.; Zhang, Y.; Dong, W.K. Mononuclear Zn(II) and trinuclear Ni(II) complexes derived from a coumarin-containing $\mathrm{N}_{2} \mathrm{O}_{2}$ ligand: Syntheses, crystal structures and fluorescence properties. Polyhedron 2018, 139, 7-16. [CrossRef]

45. Dong, X.Y.; Akogun, S.F.; Zhou, W.M.; Dong, W.K. Tetranuclear Zn(II) complex an asymmetrical Salamo-type chelating ligand: Synthesis, structural characterization, and fluorescence property. J. Chin. Chem. Soc. 2017, 64, 412-419. [CrossRef]

46. Dong, W.K.; Lan, P.F.; Zhou, W.M.; Zhang, Y. Salamo-type trinuclear and tetranuclear cobalt(II) complexes a new asymmetry salamo-type ligand: Syntheses, crystal structures and fluorescence properties. J. Coord. Chem. 2016, 65, 1272-1283. [CrossRef]

47. Li, L.H.; Dong, W.K.; Zhang, Y.; Akogun, S.F.; Xu, L. Syntheses, structures and catecholase activities of homo-and hetero-trinuclear cobalt(II) complexes constructed from an acyclic naphthalenediol-based bis(salamo)-type ligand. Appl. Organomet. Chem. 2017, 31. [CrossRef]

48. Dong, W.K.; Akogun, S.F.; Zhang, Y.; Dong, X.Y. A reversible "turn-on" fluorescent sensor for selective detection of $\mathrm{Zn}^{2+}$. Sens. Actuators B Chem. 2017, 238, 723-734. [CrossRef]

49. Ma, J.C.; Dong, X.Y.; Dong, W.K.; Zhang, Y.; Zhu, L.C.; Zhang, J.T. An unexpected dinuclear Cu(II) complex with a bis(Salamo) chelating ligand: Synthesis, crystal structure, and photophysical properties. J. Coord. Chem. 2016, 69, 149-159. [CrossRef]

50. Zhang, Y.G.; Shi, Z.H.; Yang, L.Z.; Tang, X.L.; An, Y.Q.; Ju, Z.H.; Liu, W.S. A facile fluorescent probe coumarin-derived Schiff base for $\mathrm{Al}^{3+}$ in aqueous media. Inorg. Chem. Commun. 2014, 39, 86-89. [CrossRef]

51. Yang, L.; Powell, D.R.; House, R.P. Structural variation in copper(I) complexes with pyridylmethylamide ligands: Structural analysis with a new four-coordinate geometry index, $\tau_{4}$. Dalton Trans. 2007, 9, 955-964. [CrossRef] [PubMed]

52. Wu, H.L.; Bai, Y.C.; Zhang, Y.H.; Li, Z.; Wu, M.C.; Chen, C.Y.; Zhang, J.W. Synthesis, crystal structure, antioxidation and DNA-binding properties of a dinuclear copper(II) complex with bis( $N$-salicylidene)-3-oxapentane-1,5-diamine. J. Coord. Chem. 2014, 67, 3054-3066. [CrossRef]

53. Zheng, S.S.; Dong, W.K.; Zhang, Y.; Chen, L.; Dong, Y.G. Four Salamo-type 3d-4f hetero-bimetallic $\left[\mathrm{Zn}^{\mathrm{II}} \mathrm{Ln}^{\mathrm{III}}\right]$ complexes: Syntheses, crystal structures, and luminescent and magnetic properties. New J. Chem. 2017, 41, 4966-4973. [CrossRef]

54. Chai, L.Q.; Huang, J.J.; Zhang, J.Y.; Li, Y.X. Two 1-D and 2-D cobalt(II) complexes: Synthesis, crystal structures, spectroscopic and electrochemical properties. J. Coord. Chem. 2015, 68, 1224-1237. [CrossRef]

55. Addison, A.W.; Rao, T.N.; Reedijk, J.; Rijn, J.V.; Verschoor, G.C. Synthesis, structure, and spectroscopic properties of copper(II) compounds containing nitrogen-sulphur donor ligands; the crystal and molecular structure of aqua[1,7-bis(N-methylbenzimidazol-2'-yl)-2,6-dithiaheptane]copper(II) perchlorate. J. Chem. Soc. Dalton Trans. 1984, 7, 1349-1356. [CrossRef]

56. Li, X.Y.; Chen, L.; Gao, L.; Zhang, Y.; Akogun, S.F.; Dong, W.K. Syntheses, crystal structures and catalytic activities of two solvent-induced homotrinuclear Co(II) complexes with a naphthalenediol-based bis(Salamo)-type tetraoxime ligand. RSC Adv. 2017, 7, 35905-35916. [CrossRef]

57. Tao, C.H.; Ma, J.C.; Zhu, L.C.; Zhang, Y.; Dong, W.K. Heterobimetallic 3d-4f Zn(II)-Ln(III) (Ln = Sm, Eu, $\mathrm{Tb}$ and Dy) complexes with a $\mathrm{N}_{2} \mathrm{O}_{4}$ bisoxime chelate ligand and a simple auxiliary ligand Py: Syntheses, structures and luminescence properties. Polyhedron 2017, 128, 38-45. [CrossRef]

58. Wu, H.L.; Pan, G.L.; Bai, Y.C.; Wang, H.; Kong, J. Synthesis, structure, antioxidation, and DNA-bindingstudies of a binuclear ytterbium(III) complex with bis( $N$-salicylidene)-3-oxapentane-1,5-diamine. Res. Chem. Intermed. 2015, 41, 3375-3388. [CrossRef]

59. Dong, W.K.; Ma, J.C.; Zhu, L.C.; Zhang, Y.; Li, X.L. Four new nickel(II) complexes an asymmetric Salamo-type ligand: Synthesis, structure, solvent effect and electrochemical property. Inorg. Chim. Acta 2016, 445, 140-148. [CrossRef]

60. Liu, Y.A.; Wang, C.Y.; Zhang, M.; Song, X.Q. Structures and magnetic properties of cyclic heterometallic tetranuclear clusters. Polyhedron 2017, 127, 278-286. [CrossRef]

61. Liu, P.P.; Sheng, L.; Song, X.Q.; Xu, W.Y.; Liu, Y.A. Synthesis, structure and magnetic properties of a new one dimensional manganese coordination polymer constructed by a new asymmetrical ligand. Inorg. Chim. Acta 2015, 434, 252-257. [CrossRef] 
62. Wang, L.; Li, X.Y.; Zhao, Q.; Li, L.H.; Dong, W.K. Fluorescence properties of heterotrinuclear Zn(II)-M(II) ( $\mathrm{M}=\mathrm{Ca}$, Sr and Ba) bis(salamo)-type complexes. RSC Adv. 2017, 7, 48730-48737. [CrossRef]

63. Zhang, H.; Dong, W.K.; Zhang, Y.; Akogun, S.F. Naphthalenediol-based bis(Salamo)-type homo- and heterotrinuclear cobalt(II) complexes: Syntheses, structures and magnetic properties. Polyhedron 2017, 133, 279-293. [CrossRef]

64. Dong, X.Y.; Gao, L.; Wang, F.; Li, X.Y.; Zhang, Y.; Dong, W.K. Tri- and mono-nuclear zinc(II) complexes halfand mono-Salamo chelating ligands. Crystals 2017, 7, 267. [CrossRef]

65. Wang, L.; Hao, J.; Zhai, L.X.; Zhang, Y.; Dong, W.K. Synthesis, crystal structure, luminescence, electrochemical and antimicrobial properties of bis(salamo)-based co(II) complex. Crystals 2017, 7, 277. [CrossRef]

66. Chohan, Z.H.; Arif, M.; Sarfraz, M. Metal-based antibacterial and antifungal amino acid derived Schiff bases: Their synthesis, characterization and in vitro biological activity. Appl. Organomet. Chem. 2007, 21, $294-302$. [CrossRef]

(C) 2018 by the authors. Licensee MDPI, Basel, Switzerland. This article is an open access article distributed under the terms and conditions of the Creative Commons Attribution (CC BY) license (http://creativecommons.org/licenses/by/4.0/). 